\title{
A 2600-year history of floods in the Bernese Alps, Switzerland: frequencies, mechanisms and climate forcing
}

\author{
L. Schulte ${ }^{1}$, J. C. Peña ${ }^{2}$, F. Carvalho ${ }^{1}$, T. Schmidt ${ }^{3}$, R. Julià ${ }^{4}$, J. Llorca ${ }^{1}$, and H. Veit ${ }^{5}$ \\ ${ }^{1}$ Department of Physical Geography, University of Barcelona, Barcelona, Spain \\ ${ }^{2}$ Meteorological Service of Catalonia, Barcelona, Spain \\ ${ }^{3}$ Schmidt Information- and Webdesign, Düsseldorf, Germany \\ ${ }^{4}$ FluvAlps Research Group, University of Barcelona, Barcelona, Spain \\ ${ }^{5}$ Institute of Geography, University of Bern, Bern, Switzerland \\ Correspondence to: L. Schulte (schulte@ub.edu)
}

Received: 26 February 2015 - Published in Hydrol. Earth Syst. Sci. Discuss.: 27 March 2015

Revised: 04 June 2015 - Accepted: 13 June 2015 - Published: 10 July 2015

\begin{abstract}
A 2600-year long composite palaeoflood record is reconstructed from high-resolution delta plain sediments of the Hasli-Aare floodplain on the northern slope of the Swiss Alps. Natural proxies compiled from sedimentary, geochemical and geomorphological data were calibrated by textual and factual sources and instrumental data. No fewer than 12 of the 14 historically recorded extreme events between 1480 and the termination of the Hasli-Aare river channel correction in 1875 were also identified by coarse-grained flood layers, $\log (\mathrm{Zr} / \mathrm{Ti})$ peaks and factor 1 anomalies. Geomorphological, historical and instrumental data provide evidence for flood damage intensities and discharge estimations of severe and catastrophic historical floods.

Spectral analysis of the geochemical and documentary flood series and several climate proxies (TSI, $\delta^{18} \mathrm{O}$, treerings, NAO, SNAO) identify similar periodicities of around $60,80,100,120$ and 200 years during the last millennia, indicating the influence of the North Atlantic circulation and solar forcing on alpine flood dynamics. The composite floodplain record illustrates that periods of organic soil formation and deposition of phyllosilicates (from the medium high catchment area) match those of total solar irradiance maxima, suggesting reduced flood activity during warmer climate pulses. Aggradation with multiple sets of flood layers with increased contribution of siliciclasts from the highest catchment area (plutonic bedrock) (e.g. 1300-1350, 1420$1480,1550-1620,1650-1720$ and 1811-1851 cal yr AD) occurred predominantly during periods with reduced solar irradiance, lower $\delta^{18} \mathrm{O}$ anomalies, cooler summer temperatures
\end{abstract}

and phases of drier spring climate in the Alps. Increased water storage by glaciers, snow cover and snow patches susceptible to melting processes associated with rainfall episodes and abrupt rises in temperature substantially increased surface runoff on slopes and discharges of alpine rivers. This interpretation is in agreement with the findings that the severe and catastrophic historical floods in the Aare since 1670 occurred mostly during positive SNAO (Summer North Atlantic Oscillation) pulses after years or even decades dominated by negative SNAO and cooler annual temperatures.

\section{Introduction}

Mountain regions like the Alps cover sensitive and vulnerable ecosystems which are exposed to changes in atmospheric circulation, extreme meteorological events, and the effects of land use. In the context of global climate change, it is striking that the annual mean temperatures in the Alps have increased 3 times more than the global temperature over the last 100 years (Hartmann et al., 2013). In general, the warming trend is not dependent on altitude (Hansen et al., 2010); however, the strong vertical environmental gradient, with major altitudinal limits such as the treeline, the snowline, and so on, makes the alpine area very sensitive to climate changes.

In contrast to urban gauging stations in the foreland (e.g. the Basel-Rhine station, in operation since AD 1808) data series of instrumental hydrological measurements in the in- 

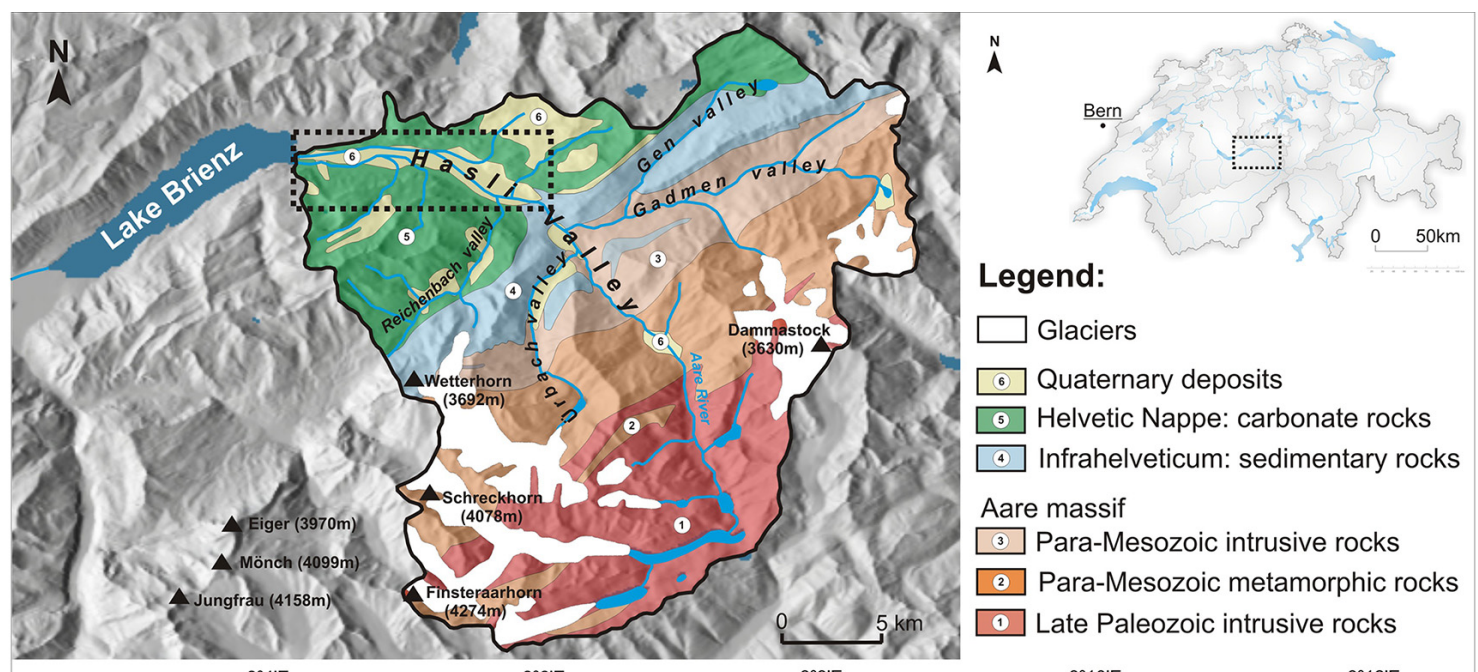

Legend:
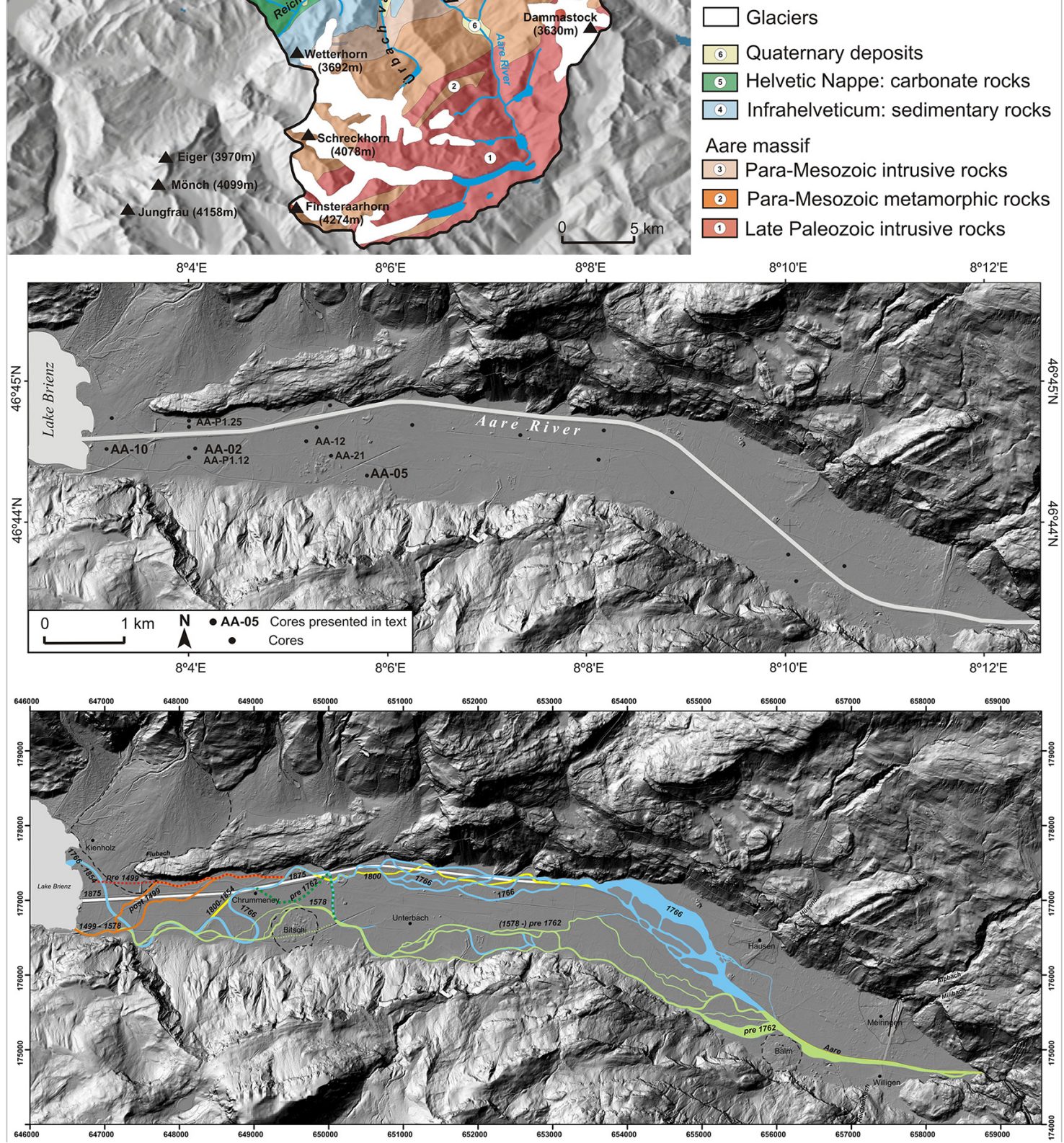

Figure 1. Geology of the Hasli-Aare catchment and digital terrain model of the Aare Delta plain in the lower Hasli Valley showing the location of retrieved cores (black dots). Labelled dots represent key cores mentioned in the text. Bottom: evolution of the Aare River palaeochannels reconstructed from historical maps, field surveys and documentary sources (this paper). Age of reconstructed channels: red discontinuous: 1251-1499; orange: post-1499; green: 1578-pre-1762; discontinuous dark green: 1551-1762; blue: 1766; yellow: 1800; white: post-Aare correction in 1875 . 
ner Alps only go back 100 years and many of the series are affected by a flood gap from AD 1937 to 1967 (Gees, 1997). The fundamental problem is that secular climate pulses (e.g. during the Little Ice Age) and low-frequency extreme events may not be recorded in these flood series. For this reason it is difficult to confidently assess floods with a return period of $>200$ years using short instrumental series, and other methods need to be applied. For example, flood reconstruction from documentary sources like chronicles, annals, paintings and flood marks provides data from Switzerland over approximately the last 750 years (Röthlisberger, 1991; Pfister, 1999; Wetter et al., 2011), encompassing the latest climatic cycles of the Holocene: the end of the Medieval Warm Period, the Little Ice Age, and the 20th century warming.

Proxy data from sedimentary records such as lake sediments (Irmler et al., 2006; Stewart et al., 2011; Wilhelm et al., 2012; Wirth et al., 2013) and floodplain deposits (Schulte et al., 2008, 2009a, 2014; Laigre et al., 2013; Carvalho, 2014) can provide data for the study of the potential effects of climatic changes on alpine floods outside the known range of extreme events reconstructed from documentary and instrumental data. Continuous high-resolution palaeohydrological time series from terrestrial sediments of floods and debris flows are generally attributed to decadal and annual records of lake sediments rather than to those of fluvial sediments (e.g. Magny et al., 2010; Wilhelm et al., 2012; Wirth et al., 2013; Glur et al., 2013). However, with the exception of the studies in Lake Bourget (Arnaud et al., 2005), Lake Silvaplana (Stewart et al., 2011) and Lake Brienz (Wirth et al., 2011), most of the alpine lakes analysed are fed by small catchments ranging from several hectares to a few kilometres squared. Due to the unequal spatial distribution of the precipitation caused by summer thunderstorms and advective rainfall events (due for example to the orientation of slopes), the question arises of whether alpine lake records show a predominantly local response to regional climate variability.

The aim of this paper is to reconstruct long time series generated from high-resolution floodplain sediments of interdistributary basins of the Hasli-Aare Delta, which reproduce the fluvial dynamics, including trends, clusters and gaps in the floods in a medium-size basin. Medium-size basins are not only influenced by local factors, but may also respond to the regional and/or global climate variability. Furthermore, the investigation of the floodplain dynamics will integrate information about human occupation and hydraulic management interacting with the fluvial systems. The study focuses on the Bernese Alps, for two reasons: firstly, the societal demand for more reliable information on the hydrological risks in a densely populated area which historically has been considered as a flood "hot spot"; and, secondly, for the possibility of calibrating geoarchives by historical sources and instrumental data. Furthermore, we will test the geochemical flood proxies by applying spectral analysis if these time series provide information regarding the frequencies of hydrological and environmental variability similar to the periodicities of
Late Holocene palaeoclimate proxies. These analyses and possible correlations contribute to the understanding of the possible driving forces behind alpine floods and the mechanisms at work.

\section{Regional setting}

The upper Aare Basin ( $46^{\circ} 41^{\prime} \mathrm{N}, 6^{\circ} 04^{\prime} \mathrm{E}$; Fig. 1), located on the northern slope of the Swiss Alps, is dominated by alpine limestone landscapes in the north and by alpine crystalline landscapes in the south, carved by Quaternary glaciers. The $596 \mathrm{~km}^{2}$ Aare catchment is subdivided into four major headwater catchments, the upper Hasli, Ürbach, Gen and Gadmen valleys, and the lower main valley, the lower Hasli Valley, which additionally is fed by several tributary basins (e.g. Alpbach, Reichenbach).

Catchment lithology (Fig. 1) is an important issue for the interpretation of geochemical proxies of key cores and for tracing sediments to establish their provenance. The northern fringe of the basin, the Helvetic Nappe (31.7\% of the catchment area; mean elevation $1578 \mathrm{~m}$ a.s.l.), consists of carbonate rocks such as limestone, schist, calcareous sandstone, marly shales and calcareous phyllite. To the south this area is limited by the Infrahelveticum ( $2.4 \%$ of the catchment area; mean elevation $2171 \mathrm{~m}$ a.s.1.), a narrow band of sandstonerich flysch and limestones. The central area of the basin (37\% of the catchment area; mean elevation $2171 \mathrm{~m}$ a.s.l.) belongs to the Aare Massif. From north to south the paraMesozoic bedrock includes granite with sericite, epidote and chlorite, feldspar-rich gneiss, and mica schist and gneiss, rich in biotite and muscovite. The southern catchment area ( $28.4 \%$ of the area; mean elevation $2528 \mathrm{~m}$ a.s.l.) is formed by basic-ultrabasic old crystalline rocks (amphibolite, diorite and gneiss) and late Palaeozoic intrusive rocks (granite, quartz diorite, syenite) forming the highest slopes and summit areas in the Aare Massif, up to an altitude of $4274 \mathrm{~m}$ at the Finsteraarhorn.

The present alpine geomorphology shows a high diversity of complex connected landforms such as cirques, glacier forefields, moraine walls, scree slopes, debris and alluvial cones, discharge channels, rock avalanches, alluvial fans and deltas. Some of these landforms result from nonlinear threshold dynamics as a consequence of the interglacial adaption cycle (e.g. rock avalanches; Huggel et al., 2012); others respond to low-frequency climate changes (e.g. Holocene moraines; Hantke, 1980), but some landforms such as alluvial fans, alluvial plains and deltas may be sensitive to intracentennial climate variability.

At $563.70(+1.63 /-1.25) \mathrm{m}$ a.s.l., Lake Brienz defines the base level of erosion of the upper Aare River system, which accumulated a $12 \mathrm{~km}$ long and $1 \mathrm{~km}$ wide delta plain limited by the slopes of the lower Hasli Valley (Fig. 1). Sedimentation rates of the floodplain range from 1.16 to $6.20 \mathrm{~mm} \mathrm{yr}^{-1}$ and sediment volumes from 15 to $26 \times 10^{6} \mathrm{~m}^{3}$ 
per 500 year time slices (Carvalho and Schulte, 2013). The floodplain morphology of the Hasli-Aare Delta, equivalent to the bottom of the lower Hasli Valley, is defined by palaeochannels, levees, crevasse splay and interdistributary basins. Sections and cores show how layers of fluvial gravels, sand and silts intertongue with organic-rich beds and peat horizons which are related to a high water table of wetland environments.

In the northern Swiss Alps, floods have mainly been triggered by precipitation anomalies such as intensive summer thunderstorms and long-lasting advective rainfall combined with pronounced snowmelt as well as glacier lake or landslide-dammed lake outburst floods (Gees, 1997; Weingartner et al., 2003). Precipitation ranges from $1175 \mathrm{~mm} \mathrm{yr}^{-1}$ at Interlaken to $2800 \mathrm{~mm} \mathrm{yr}^{-1}$ at the summit level of the Aare Massif. According to the instrumental hydrological data recorded since 1905 at the Brienzwiler gauging stations, the hydrological regime is defined as nival-glacial, taking into account the fact that approximately $17 \%$ of the catchment area is covered by glaciers. The mean discharge of Aare River is $35 \mathrm{~m}^{3} \mathrm{~s}^{-1}$ at the Brienz gauging station, with a maximum discharge of $444 \mathrm{~m}^{3} \mathrm{~s}^{-1}$ being recorded on 22 August 2005.

In spite of the potential geographical marginality of high mountain regions such as the Alps, periods of increased land use have been recorded since the Bronze Age (Schaer, 2003; Guyard et al., 2007; Ebersbach et al., 2010) and various adaptation and mitigation strategies for natural hazards have been developed. In some areas these strategies are still part of the cultural landscape and settlement pattern. Since AD 1876, the lower Aare stretch has been channelized and since AD 1932 reservoirs for hydroelectric power have influenced flood dynamics due to changes in their retention capacities. As the result of the development of grazing, agriculture, industry, tourism and infrastructure, the AD 2000 census recorded a population of 8190 inhabitants in the upper Aare Basin. Furthermore, the population densities of the municipalities in the lower Hasli Valley (50-100 inhabitants km ${ }^{-2}$ ) are among the highest per productive area in the Alps. However, the limited space in the Hasli Valley that is suitable for settlement is mostly to be found in alluvial fans and trough shoulders. In contrast to the nearby Lütschine Delta, no towns or villages are located in the Hasli-Aare Delta floodplain (with the exception of the small municipality of Unterbach). However, present-day human activities (e.g. tourism) are not limited to traditional low-risk areas, due to the demographic pressure during the 19th and 20th centuries and the introduction of hydraulic management of the floodplains. Furthermore, infrastructures such as highways, power lines, hydroelectric power stations, gas pipelines, railway tracks and the Meiringen Air Base are all exposed to flood hazards.

\section{Methods}

The integrated multi-proxy approach focuses on the Late Holocene flood dynamics in the lower Hasli Valley, the main alpine valley in the upper Aare River. Palaeoflood frequencies were reconstructed from geoarchives, particularly from alluvial delta plain sediments (Sect. 3.1), geochemical records (Sect. 3.2) and their calibration by data series from historical sources and instrumental data (Sect. 3.3). Frequencies of various time series such as palaeoflood proxies, historical flood records, and climate variability were investigated (Sect. 3.4).

\subsection{Geoarchives from delta floodplains}

Mesoscale fluvial landforms were mapped in the delta floodplain of the lower Hasli Valley by a geomorphological survey and analysis of historical aerial photographs (AD 19281944), IR and SPOT images, historical maps and a $2 \mathrm{~m}$ spatial resolution digital terrain model. Different sedimentary facies were identified depending on the floodplain morphology, changing environments, and river dynamics. Channel and crevasse splay deposits are generally composed by coarse sand and gravel, levees by sand layers, and overbank deposits by fine sand and silt, and interdistributary basins contain clay-rich and organic-rich layers as well as peat horizons. River channel shifts and avulsion may cause erosion and redeposition, whereas sediments in intradistributary basins are deposited conformably. Thus, according to the results from the Lütschine Delta (Schulte et al., 2008), alluvial plain sediments provide excellent geoarchives for reconstructing the Late Holocene aggradation and flood history. During larger floods these basins record aggradation of coarse-grained flood layers; during moderate floods, finesand and silt deposits are formed, and organic-rich horizons and peat during minor floods or flood gaps. Therefore, peat layers are marker horizons that represent stable land surfaces, a high water table, and minimum sediment contribution.

A total of 16 cores were obtained by percussion coring down to $10 \mathrm{~m}$ depth. The lateral extension of the major units was traced by four cross sections of $20 \mathrm{~m}$ spaced shallow drillings (85 cores). Sediments, organic soil horizons and peat layers were described macromorphologically and wood, plant, mollusc fragments and artefacts were collected and classified. Sediment structures, facies and associated geomorphic processes as well as the mineralogy of selected flood layers were analysed in thin sections. Furthermore, sedimentological data were compiled from core inventories provided by the geological database of the Bureau of Water Management of the Bern Canton (WWA).

The most detailed sedimentary records in the Hasli-Aare floodplain, in terms of lithological-geochemical and temporal resolution, were retrieved from interdistributary basins and their lateral transitional landforms. In this paper we focus on three key cores: AA-10, at a distance of $200 \mathrm{~m}$ from the 
Table 1. Categories of historical Aare floods in the Hasli Valley.

\begin{tabular}{|c|c|c|}
\hline Event category $\left(M_{\mathrm{AA}}\right.$ and $\left.M_{i}\right)$ & Primary indications & Secondary indications \\
\hline 1 & - Flood and minor damage is reported & - Short-duration, local flooding \\
\hline 2 & $\begin{array}{l}\text { - Damage or destruction of a few } \\
\text { buildings close to the river } \\
\text { - Damage to hydraulic infrastructure } \\
\text { (e.g. bridges and levees) } \\
\text { - Aggradation on landforms } \\
\text { close to the channel }\end{array}$ & $\begin{array}{l}\text { - Flooding at several stretches of } \\
\text { the river, small pounded lakes } \\
\text { - Evacuation, people flee from flood } \\
\text { - Low number of fatalities }\end{array}$ \\
\hline 3 & $\begin{array}{l}\text { - Severe damage or destruction of several } \\
\text { buildings or entire villages } \\
\text { - Loss of productive farm land due } \\
\text { to massive aggradation and major } \\
\text { shifts of river channels }\end{array}$ & $\begin{array}{l}\text { - Flooding of the entire valley bottom } \\
\text { and/or of areas at distance to channel } \\
\text { - Fatalities, migration, interregional assistance, } \\
\text { donations, poverty, food shortage, etc. } \\
\text { - Subsequent action: policy, river regulation, etc. }\end{array}$ \\
\hline
\end{tabular}

delta shore line; AA-02, at a distance of $1.5 \mathrm{~km}$; and AA-05, at a distance of $4.5 \mathrm{~km}$ (Fig. 1). The age-depth models are based on 11 AMS (accelerator mass spectrometry) radiocarbon datings (Table 1 in Supplement) of peat, wood and plant remains analysed at the Tandem Laboratory, Uppsala, and compared to the chronology of other core sites in the study area (Schulte et al., 2008, 2009a, b; Carvalho and Schulte, 2013). From our experience with 161 radiocarbon datings, we suggest that radiocarbon ages of peat and wood (when not removed) show consistent and reproducible ages that correlate at different sites. Radiocarbon dating of bulk sediment, plant remains and charcoal frequently show reversal of ages, due to sample contamination by reworked older organic-rich beds and redeposition processes. Radiocarbon ages were rejected when they disagreed with the sample's stratigraphic position. The chronology of each core sample was calculated from age-depth models based on linear interpolation between the calibrated ages calculated with the CALIB Radiocarbon Calibration program Version 7.0 (Stuiver et al., 2014). The mean resolution of the sediment accumulation rate of our original sedimentary records is $0.25 \mathrm{~cm} \mathrm{yr}^{-1}$. Each sample taken at intervals of $1 \mathrm{~cm}$ integrates 4 years. Calibration of the geochronological model was performed firstly by identification of historical flood layers and metal anomalies (from the last century), secondly by the correlation of marker horizons and major geochemical anomalies and, thirdly, by the comparison of possible synchronized trends and variability of geochemical proxies and palaeoclimate records. For example, age-depth models were corrected within maximum probability intervals (Magny et al., 2011) where regular displacement of peaks in our data series were observed compared to other climate records such as the $\delta^{18} \mathrm{O}$ curve. For detailed information on the radiocarbon dating, the reader is referred to Table S1 in the Supplement and to Carvalho and Schulte, 2014; and Carvalho, 2014.

\subsection{Geochemical flood proxies}

To investigate the geochemical variations of the alluvial plain sediments during the last 2600 years, the element composition of the samples retrieved was analysed by X-ray fluorescence (XRF) core scanning techniques (MARUMUniversity of Bremen) and by conventional XRF (Central Laboratories of the University of Barcelona). The XRF core scanning techniques (Avaatech Serial No. 2; Canberra XPIPS Silicon Drift Detector) provide non-destructive analysis of split core surfaces collecting down-core data at $1 \mathrm{~cm}$ intervals over a $1.2 \mathrm{~cm}^{2}$ area (Röhl and Abrams, 2000). The data were acquired by a Canberra X-PIPS Silicon Drift Detector with $150 \mathrm{eV}$ X-ray resolution, the Canberra Digital Spectrum Analyser DAS 1000, and an Oxford Instruments 50W XTF5011 X-Ray tube with rhodium (Rh) target material. The following X-ray tube settings were used: elements $\mathrm{Al}, \mathrm{Si}, \mathrm{S}$, $\mathrm{K}, \mathrm{Ca}, \mathrm{Ti}, \mathrm{Mn}, \mathrm{Fe}$ at $10 \mathrm{kV}, 0.35 \mathrm{~mA}$ and $30 \mathrm{~s}$; Rb, Sr, Zr, Pb and $\mathrm{Br}$ at $30 \mathrm{kV}, 0.75 \mathrm{~mA}$ and $60 \mathrm{~s}$; and $\mathrm{Cu}$ at $20 \mathrm{kV}, 0.25 \mathrm{~mA}$ and $30 \mathrm{~s}$.

Because the XRF-scan results (counts per area) express the relative variability of fluorescence according to the different excitation of the atoms in the substance in response to bombardment by incident energy, it was not possible to obtain comparable percentages of element contents. Therefore, calibration of individual samples with maximum anomalies was carried out by conventional X-ray fluorescence. In addition, lighter elements such as $\mathrm{MgO}, \mathrm{P}_{2} \mathrm{O}_{5}$ and $\mathrm{NaO}$ could also be measured. Spectrometric measurements were undertaken on pearls using a Philips PW 2400 spectrometer to estimate the of major element contents of 82 samples collected from the split cores. The major elements were quantified by a calibration curve generated by 58 international reference samples in pearls.

For comparison of $\mathrm{CaCO}_{3}$ content, loss on ignition (LOI) at $950{ }^{\circ} \mathrm{C}$ was punctually measured following Heiri et al. (2001) and Santisteban et al. (2004). In addition, total 
organic carbon (TOC) content was analysed systematically down-core by $\mathrm{LOI}$ at $550^{\circ} \mathrm{C}$ at $1 \mathrm{~cm}$ steps. TOC values of wood remains were removed case by case from the data set to avoid alteration of the geochemical proxy.

To generate environmental proxies from delta plain sediments, the geochemical variability of the core samples was analysed in a series of steps. First, series of individual elements were plotted versus lithology, grain size and total organic carbon along with sample depth. Second, elements were analysed as Ti ratios, because of the conservative nature of Ti during transport and weathering (Kylander et al., 2011), in order to remove possible alterations in XRF-scan intensities caused by pore volume, the changing roughness of the split core surface (counts per area decrease with increasing roughness) and so on. Third, factor analysis (FA) was computed with the STATISTICA 6 software to explore the variability of the geochemical data sets (Schulte et al., 2009a). The first two factors were extracted (rotated and unrotated) from TOC values and the geochemical data matrix (original data and Ti ratios). The scores were plotted applying the geochronological model and then compared to data series of palaeoclimate records, such as reconstructed temperature and precipitation curves of the Alps (Büntgen et al., 2011), the Greenland $\delta^{18} \mathrm{O}$ record (GISP2; Reimer et al., 2004) and total solar irradiance (TSI; Steinhilber et al., 2009). For this comparison a composite sedimentary palaeoflood proxy was generated from cores AA-02 and AA-05 at a 21-year resolution taking the accumulation rate between pairs of contiguous radiocarbon ages.

To investigate the provenance, deposition and diagenetic processes of the materials, minerals such as quartz, feldspar, chlorite, calcite and pedological features were microscopically identified in thin sections and factor analyses were also applied to conventional XRF data, TOC and grain-size fractions of selected samples.

Furthermore, the $\mathrm{Zr} / \mathrm{Ti}, \mathrm{Zr} / \mathrm{Rb}$ and $\mathrm{Sr} / \mathrm{Ti}$ ratios were compared with grain-size fractions (laser diffraction grain size analyser) and macroscopically and microscopically analysed coarse-grained flood layers to produce grain-size flood proxies of three intensity levels (M1: silty fine sands, M2: fine sands, M3: middle and coarse sands). In contrast with the results of Jones et al. (2012) on the geochemical flood records of the upper River Severn in mid-Wales (UK), the $\mathrm{Zr} / \mathrm{Ti}$ ratio calculated in the delta floodplain sediments of the lower Hasli Valley was a more sensitive signal than the $\mathrm{Zr} / \mathrm{Rb}$ ratio. Finally, the frequency and magnitude of flood layers and $\mathrm{Zr}$ / Ti peaks were compared to the historical flood index reconstructed from documentary sources (Sect. 3.3).

\subsection{Historical flood series and instrumental data}

Flood series of the upper Aare (Hasli Valley) were compiled from textual sources (local and regional historical monographs, newspapers, scientific reports, reports of local and regional authorities, chronicles, the parish regis- ter) and factual sources (historical maps, historical paintings and photographs) (Pfister, 1999). These reconstructed flood events were compared to episodes recorded in existing flood databases for Switzerland provided by Röthlisberger (1991) for the period AD 1020-1988, Pfister (1999) for the period AD 1496-1995, Gees (1997) for the period AD 1800-1994, Hählen (2007, Civil Engineering Department of the Bern Canton) for the period AD 1600-2005 and digital flood archives provided by the Swiss Flood and Landslide Damage Database of the Swiss Federal Institute for Forest, Snow and Landscape Research for the period AD 1972 2009. Singular flood events were also compared to instrumental precipitation records of the IDAWEB database provided by MeteoSwiss precipitation data from the stations of Guttannen since AD 1876 and Meiringen since AD 1898. Information on discharges of the upper Aare River was taken from the records of the Brienzwiler gauging station located $1.4 \mathrm{~km}$ from Lake Brienz, since AD 1905 (data provided by BUWAL).

Original flood descriptions were analysed to locate the reported damage geographically, to estimate the flooded area and to reconstruct the type and magnitude of damage. Reported geomorphic processes such as channel migration and aggradation were validated by the geomorphological data obtained by mapping and the sedimentological data by coring along cross sections as described in Sect. 3.1. In addition, useful information was also obtained via comparisons between the spatial evolution of the Hasli-Aare floodplain and the descriptions of the historical road network reconstructed by the Swiss Inventory of Thoroughfares (Inventar Historischer Verkehrswege der Schweiz, 1992).

To estimate historical flood intensities between AD 1480 and 2012, in the first step primary and secondary indications were defined for classifying floods according to the scale of the damage and geomorphic change (Table 1). Although several flood classifications and typologies have been proposed by a large range of publications (Röthlisberger, 1991; Pfister, 1999; Sturm et al., 2001), in the present study we adapted the flood criteria to local physiographic, socio-economic and demographic settings of the Aare and Lütschine catchments.

In the second step, the tributary catchments were included in order to consider the spatial dimension. In the case of the Aare River, flood categories in the bottom of the lower Hasli Valley were multiplied by a factor of 1 , whereas flood categories in the tributaries and headwater catchments were multiplied by 0.5 . This higher weight is attributed to the floods in the stretch of the lower Hasli-Aare $\left(M_{\mathrm{AA}}\right)$ because floods in the main valley normally result from higher discharges from several subcatchments (e.g. the floods of AD 1762 and 1831), while discharges that cause severe damage in a tributary $\left(M_{i}\right)$ do not necessarily generate significant flooding in the main valley (e.g. the floods of AD 1869 and 1915). Finally, the total flood intensities of the Aare River (M) are defined as the sum of both flood categories. Flood event intensities of $<2$ are considered as small and medium sized, those $\geq 2$ are se- 
vere and those $\geq 3.5$ are catastrophic. The maximum value of 4.5 was reached in $\mathrm{AD} 1762$. The equation is

$M=M_{\mathrm{AA}}+\sum_{i=1}^{n}\left(M_{i} \cdot 0.5\right)$,

where $n$ is the number of flooded tributaries.

The precision and continuity of historical flood data series may change over time. In particular, information on small and medium flood categories before AD 1850 is limited. The data became more reliable after the introduction of the Swiss federal law on river correction in AD 1854, and improved over the course of the 19th century due to the increased information available in the press. As for severe and catastrophic flood episodes, several authors (Röthlisberger, 1991; Gees, 1997; Pfister, 1999; Wetter et al., 2011) note that they are generally well recorded in Switzerland due to their impact on society. Flood mitigation management was implemented in the Bernese Alps as early as the 13th century (Vischer, 2003) and more frequently since the 18th and 19th centuries (Wetter et al., 2011).

\subsection{Spectral analysis of flood and climate series}

Segments of the geochemical data series of cores AA-02, AA-05 and AA-10 (Sect. 3.2) show a quasi-cyclic variability (Schulte et al., 2014). To explore the frequencies of this variability, the data were processed by spectral analysis (Schulz and Statteger, 1997; Schulz and Mudelsee, 2002). Frequency analyses were also applied to the historical flood series of the upper Aare catchment (Sect. 3.1) and other palaeoclimate records such as $\delta^{18} \mathrm{O}$ anomalies (the GISP 2 record from Greenland; Stuiver et al., 1997), $\delta^{14} \mathrm{C}$ anomalies (Reimer et al., 2004) and reconstructed temperature and precipitation curves from the Alps (Luterbacher et al., 2002; Büntgen et al., 2011). To detect periodic signals in unevenly spaced time data series, a harmonic analysis (Percival and Walden, 1993) was performed using the SPECTRUM software (Schulz and Statteger, 1997). The periodograms were calculated from the Lomb-Scargle Fourier transform with a rectangular window, using a significance level of 0.05 and $\lambda$ of 0.4. This configuration detects a false-alarm level of $99.6 \%$ for white noise assessment through the Siegel test (Siegel, 1979). The rednoise spectra of the records have been processed with the REDFIT software (Schulz and Mudelsee, 2002).

\section{Results}

\subsection{Aggradation processes in the floodplain}

The key-cores retrieved from the Hasli-Aare floodplain (Figs. 1, 2) show alluvial delta plain facies defined by sequences of shallow gravel channel beds, sandy levee and crevasse splay deposits, coarse-grained flood layers within overbank deposits, palustrine fine-grained sediments, organic-rich beds and peat horizons. From lithostratigraphical data an aggradation model of the Hasli-Aare floodplain is reconstructed, showing two different patterns of floodplain dynamics: first, abrupt channel shifts, occasionally from one edge of the valley floor to the opposite; and, second, the vertical channel aggradation, combined with minor horizontal displacements. This pattern tends to produce a dissymmetry of the valley floor topography. In addition, these dynamics may be reinforced by the slow subsidence produced by the compaction of delta sediments.

For example, in AD 1766 the engineer Mirani (1766) measured differences in height of up to $5.4 \mathrm{~m}$ between the southern and the northern edges of the valley (Willi, 1932; Fig. 1). Under this predisposition the river can break through levees during larger floods, thus changing its course towards the lowest parts of the valley (e.g. interdistributary basins). Consequently, a new cycle of progressive aggradations begins. In four cross sections the following shifts were identified: between 957 and $1251 \mathrm{cal} y \mathrm{AD}\left({ }^{14} \mathrm{C}\right.$ dating; cores AA-02 and AA-P1.25) and AD 1762 (historical sources and ${ }^{14} \mathrm{C}$ dating; Aa-P1.12; Fig. 1). A third mechanism of channel shift was introduced by large landslides and debris flows such as the Bitschi landslide, dated by radiocarbon between $574 \pm 172 \mathrm{cal} \mathrm{yr} \mathrm{BC}$ and $158 \pm 80 \mathrm{cal} \mathrm{yr} \mathrm{AD}$ (core AA$12 ; 56 \pm 32$ cal yr AD, core AA-21), the large Kienholz debris flow of AD 1499 (which destroyed the castle of Kienholz), the Balm landslide of AD 1650, and to a lesser extent the active scree slope southwest of Krummeney (until the 1860s).

Over the last centuries anthropogenic activity has become a major driver of floodplain dynamics. In the Hasli-Aare catchment a number of structural hydraulic measures have influenced the floodplain dynamics in the lower Hasli Valley: (1) the construction of the river barrier at the outlet of Lake Brienz, raising it by 1.50-1.95 m between AD 1434 and 1865 (Willi, 1932; Kurz and Lerch, 1979), thus affecting the distal area of the Aare Delta; (2) the repeated levee construction and maintenance as well as the local river detour created by the local river management cooperative in AD 1579 (Willi, 1932); (3) the correction of the Aare River in AD 1876, channelling and straightening the riverbed from the Aare gorge to the river mouth; and (4) the operation of several connected reservoirs to produce hydroelectric power since AD 1933. However, flood mitigation, ground sealing, deforestation, reforestation, and changing land-use practices have opposite effects which may partially compensate for each other (Pfister, 1999).

\subsection{Sedimentary delta plain records}

In general, the $10 \mathrm{~m}$ deep core AA-05 reflects low energy deposition environments of a marginal basin located at the southern valley floor at a distance of $4.5 \mathrm{~km}$ from Lake Brienz (Fig. 1). The basin is protected upstream by a landslide deposits which diverted the Aare northwards during the 


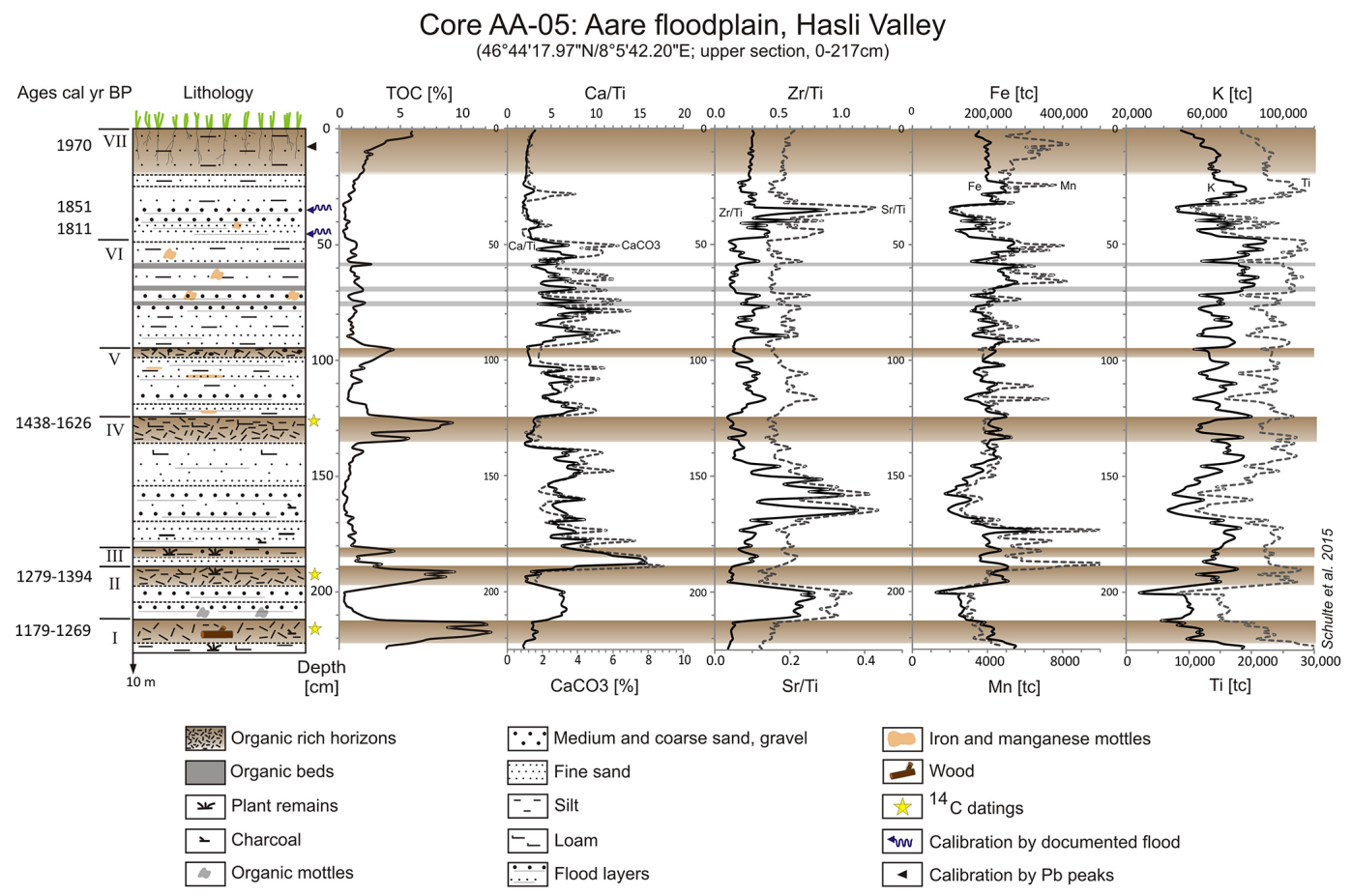

Figure 2. Lithology, chronology and geochemical stratigraphy of key core AA-05. The bars represent organic horizons and beds.

last 3000 years. Sand and silt beds deposited during multiple aggradation pulses are intercalated by 14 organic horizons. The geochronological model of the last 2600 years was established by six AMS radiocarbon ages (supplementary material; Table 1). The flood layers of the youngest units (unit VII) were calibrated by historical sources (AD 1811 at $36 \mathrm{~cm}$ depth and AD 1851 at $44 \mathrm{~cm}$ depth; Figs. 2, 3). The established chronology was tested by comparing the interpolated age of the $\mathrm{Pb}$ peak (AD 1967 at $7 \mathrm{~cm}$ depth) with the maximum consumption of unleaded gasoline around AD 1970 (Weiss et al., 1999).

In the Hasli-Aare floodplain the water table is very close to the surface, ranging between 1.4 and $2.5 \mathrm{~cm}$ in depth. Therefore, hydromorphic dynamics are relevant for the interpretation of geochemical records. For example, Mn and Fe values mostly show a positive correlation, particularly in fine-grained layers, when they are bound in the clay lattice (Tebbens et al., 2000). Minimum values of both elements are recorded in sandy flood layers (Fig. 2). However, the $\mathrm{Mn} / \mathrm{Fe}$ ratio, used by several authors as an indicator of palaeoredox conditions (Koinig et al., 2003), decreases in the organic horizons where organic decomposition generates oxygen depletion, contributing to anoxic conditions and mobilization of $\mathrm{Mn}(\mathrm{II})$. Also important is the effect of groundwater dynamics on carbonates. In core AA- 05 , carbonates are leached below the depth of $213 \mathrm{~cm}$, whereas above this depth $\mathrm{CaCO}_{3}$ $(\mathrm{Ca} / \mathrm{Ti})$ shows a sensitive variability with maximum values of about $7 \%$ (Fig. 2). To avoid inhomogeneous time series and to investigate the geochemical proxy with maximum res- olution, in this paper the analysis of core AA- 05 focuses on samples from between a depth of $217 \mathrm{~cm}$ and the surface.

Figure 2 shows seven major deposition pulses (units IVII) of upward thinning sequences. The aggradation of sandy overbank deposits during major flooding is accurately recorded by $\mathrm{Zr} / \mathrm{Ti}, \mathrm{Sr} / \mathrm{Ti}$ and $\mathrm{Ca} / \mathrm{Ti}$ peaks associated with coarse-grained flood layers (Fig. 2). Silty paludal beds, which reflect decreased sediment contribution during minor floods, show high values of $\mathrm{K}$, Ti and $\mathrm{CaCO}_{3}$ and frequently contain disperse organic matter and plant remains. The organic beds and soil horizons (4-12\% TOC) at the top of each cycle (at depths of 90, 125, 188 and $213 \mathrm{~cm}$ ) correspond to relatively calm deposition environments or even to stable conditions without flooding.

The catchment lithology is reflected by thin section micromorphology. Eighteen samples retrieved from flood layers of cores AA-05 and AA-10 show quartz / feldspar ratios of grains $(30-1500 \mu \mathrm{m})$ ranging from 0.4 to 0.7 . Low ratios point to the dominance of feldspar contribution from the plutonic bedrock in the highest terrain of the Aare catchment, particularly during cooler climate pulses (Sect. 5.1).

The $6 \mathrm{~m}$ deep core AA-02, retrieved from a central interdistributary basin located in the axis of the lower Hasli Valley floor $2 \mathrm{~km}$ from the lake shore, records nine major aggradation pulses over the last 2600 years. Coarse channel deposits of the Aare River were drawn from $800-650 \mathrm{~cm}$ depths. The aggradation of the channel facies then ceased abruptly, probably due to channel abandonment, and continued through the deposition of organic and silty material from palustral en- 


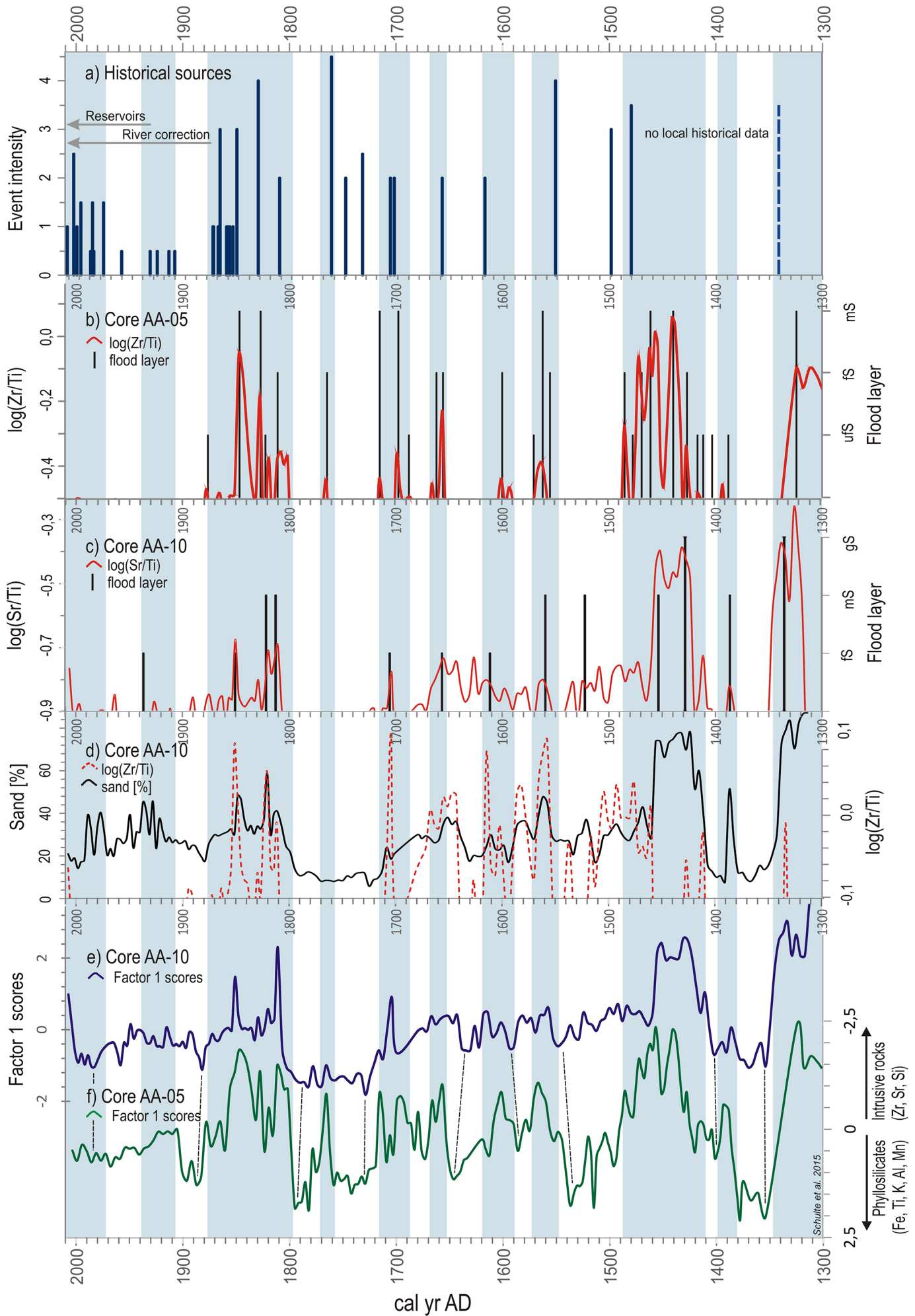

Figure 3. Chronostratigraphy of cores AA-05 and AA-10 and comparison with historical Aare floods in the Hasli Valley. Time series are plotted in calibrated calendar years (cal yr AD). Each sample taken from cores at intervals of $1 \mathrm{~cm}$ integrates 3.8 years. No filters were applied to the data series. (a) Flood data series reconstructed by historical sources (columns) and archaeological data (dashed column). (b) $\log (\mathrm{Zr} / \mathrm{Ti})$ values > -0.5 and coarse-grained flood layers (ufS: silty fine sand; fS: fine sand; $\mathrm{mS}$ : middle sand) of $\operatorname{core} \mathrm{AA}-05$. (c) $\log (\mathrm{Sr} / \mathrm{Ti}) \mathrm{values}$ $>-0.9$ and coarse-grained flood layers (fS: fine sand; $\mathrm{mS}$ : middle sand; gS: coarse sand) of core AA-10. (d) Sand fraction (630-2000 $\mu \mathrm{m})$ and $\log (\mathrm{Zr} / \mathrm{Ti})$ values $>-0.1$ of core AA-10. (e, f) factor 1 scores of chemical composition of core AA-10 and AA-05 samples (reverse). 
vironments. After 2220 cal yr BP, the influence of the Aare River is again more noticeable. Between the depths of 470 and $220 \mathrm{~cm}$, multiple pulses of overbank deposition show a general trend of upward fining sedimentation. The upper unit (50-220 cm depth) contains four peat horizons with up to $45 \%$ total organic carbon. The presence of minerotrophic fens in the central area of the floodplain lasted more than half a millennium, from 1450-1000 cal yr BP, until alluvial floodplain sedimentation started again.

The mean chemical composition of the sediments of core AA-02 reflects the dominance of $\mathrm{SiO}_{2}(74 \%), \mathrm{Al}_{2} \mathrm{O}_{3}(18 \%)$ and $\mathrm{Fe}_{2} \mathrm{O}_{3}(7 \%)$ due to the fact that $65 \%$ of the catchment consists of crystalline bedrock of the Aare Massif (Fig. 1). Although more than $30 \%$ of the Aare catchment area contributes carbonate-rich sediments to the river system, $\mathrm{Ca}$ counts are very low in the total data series of core AA-02. According to the $\mathrm{X}$-ray diffraction analyses, $\mathrm{CaO}$ values of up to a maximum of $2 \%$ are related to hornblende and not to carbonates. The absence of carbonates in the fine-grained beds (except for the lower gravel deposits) suggests (a) efficient carbonate leaching by acidic water in peat wetland environments, and (b) the dominance of phyllosilicates as a source of fine-grained materials (the metamorphic rocks of the Aare Massif).

Two units of different facies were detected at core site AA10 , located $200 \mathrm{~m}$ from Lake Brienz. The lower unit (between depths of 1.80 and $12.00 \mathrm{~m}$ ) consists of clean coarse sand and fine gravel which were deposited on the delta front, whereas the upper unit $(0-1.80 \mathrm{~m}$ depth) shows sandy floodplain deposits. In the paper we refer only to the delta plain deposits of the upper unit, which cover the last 700 years. The chronology of AA-10 was based on the correlation of beds with characteristic flood layers and fine-grained still water deposits of core AA-05. In addition, the metal peaks of the 20th century, such as the $\mathrm{Pb}$ peak at $9 \mathrm{~cm}$ depth and $\mathrm{Zn}$ peak at $20 \mathrm{~cm}$ depth (the latter peak may be associated with pre-WW I zinc tin production; Weiss et al., 1999) were identified. Radiocarbon ages on charcoal and plant fragments were rejected because they show reversals of age due to redeposition processes of charcoal and plant remains in the distal delta floodplain environment. After correction of the geochronological model, the geochemical variability (factor 1 scores) of AA-10 shows a very close correlation with the variations of core AA-05 (Fig. 3; Sect. 4.3).

\subsection{Geochemical palaeoflood proxies}

The youngest sediments $(217-0 \mathrm{~cm}$ depth) at the key site AA-05 provide a good opportunity to study flood dynamics from alluvial plain sediments and their related mechanisms at a high resolution. Seven clusters of coarse-grained flood layers intertongue five organic soil horizons (TOC 4$11 \%$ ) and silt-rich still-water deposits. Figure 3 shows that the $\log \mathrm{Zr} / \mathrm{Ti}$ ratio of core AA-05 (AA-10) samples above $-0.5(-0.1)$ correspond to flood layers, thus providing a palaeoflood proxy. However, the $\log \mathrm{Zr} / \mathrm{Ti}$ ratio of core AA-10 shows a reverse pattern between depths of 156 and $188 \mathrm{~cm}$ (1460-1350 cal yr BP; Fig. 2), while the $\log \mathrm{Sr} / \mathrm{Ti}$ ratio indicates a significant positive correlation with flood layers $(\mathrm{Sr} / \mathrm{Ti}>-0.85)$ and sand fraction $(r=0.72$; Fig. 2$)$ throughout the entire record. We stress that the ratios of these stable elements provide information of two kinds: grain size, and provenance of sediments. $\mathrm{Zr}$ is frequently enriched in coarse silt and sand in association with quartz (Kylander et al., 2011) which is present in many types of bedrock throughout the Aare catchment. At the same time, zircon is also a tracer for sediment supply from the highest area of the basin (mean altitude: $2528 \mathrm{~m}$ a.s.l.) because this heavy mineral is present in the crystalline rocks such as syenite, granite and amphibolites of late Palaeozoic intrusions. The element $\mathrm{Ti}$, the denominator of these ratios, is related to clay mineral assemblages and to phyllosilicates located in the paraMesozoic metamorphic rocks of the central area of the Aare catchment (mean altitude: $2171 \mathrm{~m}$ a.s.l.). Finally, $\mathrm{Sr}$ values are associated with both carbonates and silicates, as reported by Kylander et al. (2011) and illustrated in Fig. 4.

Factor analysis (FA) is a powerful tool for inferring palaeoenvironmental processes from geochemical variables of a sediment record, as exemplified by the data of core AA05 (Fig. 4a). Factor 1 (F1) explains $47.9 \%$ of the variability of the geochemical properties of the samples measured by $\mathrm{XRF}$ core scanning. It is defined by a strong positive loading of $\mathrm{Fe}, \mathrm{Ti}, \mathrm{Rb}, \mathrm{K}, \mathrm{Al}$ and $\mathrm{Mn}$ (phyllosilicate components such as biotite and $\mathrm{K}$ feldspars in gneiss and other metamorphic rocks), a strong negative loading of $\mathrm{Zr}$ (associated with heavy minerals like zircon and also with quartz) and $\mathrm{Sr}$ (associated with carbonates and plagioclase), while the loadings of $\mathrm{Si}$ and $\mathrm{Ca}$ are not significant. The second factor (F2; $22.8 \%$ of total variance) demonstrates positive loadings of metals $(\mathrm{Pb}$, $\mathrm{Zn}, \mathrm{Cu}$ ) associated with organic material (TOC) and negative loadings of $\mathrm{Si}, \mathrm{Al}$, and $\mathrm{K}$, associated with siliciclastic rocks.

Factor analysis was also applied to 27 calibration samples in which grain size data and conventional XRF data were obtained (Fig. 4b). The first two factors are defined by an element distribution very similar to that of the FA of scanned XRF samples. Despite the reversals of factors F1 and F2, the groups of the variables are equivalent to the scanned samples and show a noticeable relation to grain size: $\mathrm{Zr}, \mathrm{Sr}$ and $\mathrm{Na}_{2} \mathrm{O}$ are related to the sand fraction, phyllosilicates to silt, and metals and TOC to clay. We suggest that there is a lithological control of the chemical composition of the samples (Schulte et al., 2009a) because several variables are grouped in characteristic pairs: $\mathrm{Pb}-\mathrm{TOC}$ (metal-organic complexes), $\mathrm{Zn}$-clay (enrichment due to increased adsorption surfaces), $\mathrm{Rb}-\mathrm{K}_{2} \mathrm{O}$ (K-feldspars), $\mathrm{Fe}_{2} \mathrm{O}_{3}-\mathrm{MgO}$ (biotite, e.g. in gneiss), $\mathrm{Sr}-\mathrm{Na}_{2} \mathrm{O}$ (plagioclase e.g. in quartz diorite; a less close relation) and $\mathrm{Zr}$-sand (heavy minerals in the plutonic area).

These findings coincide with the results of core AA- 10 . The 2-D plot (not shown) of loadings shows the following groups of variables: metals and TOC associated with the clay 


\section{Factor loadings of geochemical properties of core samples}

a) Core AA-05, XRF-core scanning $(n=200)$

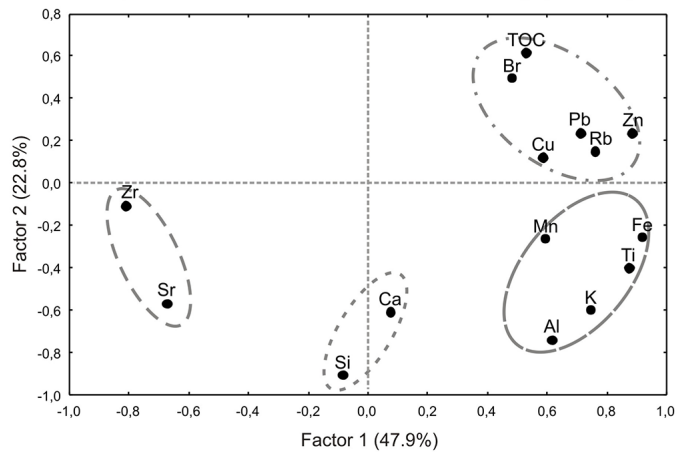

c) Core AA-02, XRF-core scanning ( $n=551)$

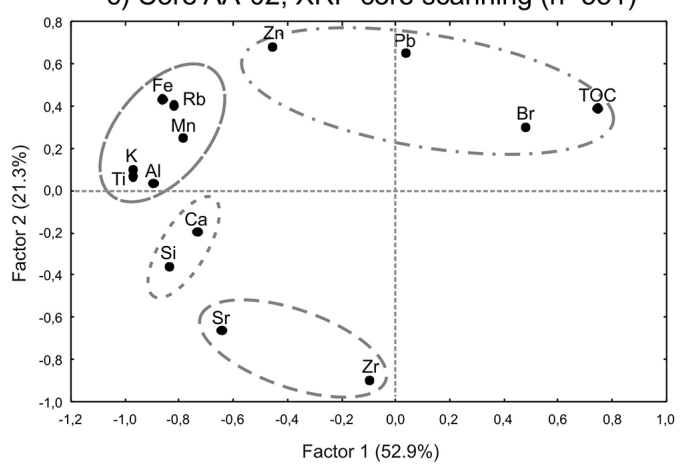

(-) Trace elements ( $\mathrm{Zr}, \mathrm{Sr})$ and sand fraction

$\because \cdots$ Silica and calcium b) Core AA-05, XRF perls $(n=27)$

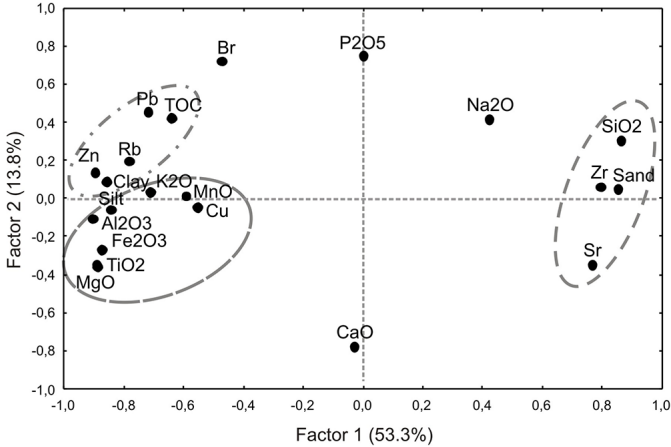

d) Core AA-02, XRF-core scan. and texture $(n=300)$

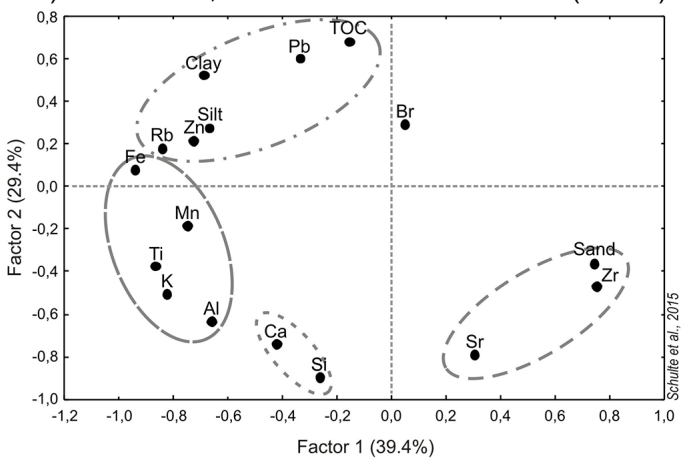

Phyllosilicates (Al, K, Ti, Mn, Fe) and silt fraction

... Metals ( $\mathrm{Zn}, \mathrm{Pb}, \mathrm{Cu}), \mathrm{TOC}$ and clay fraction

Figure 4. 2-D plots of factor loadings (factor analysis) of chemical major and minor elements, TOC and grain-size fractions of core AA-02 and AA-05 samples.

fraction (soil formation), phyllosilicates related to the silt fraction (metamorphic rocks) and, finally, a group defined by the elements $\mathrm{Zr}, \mathrm{Sr},(\mathrm{Al})$ and $\mathrm{Si}$ (plutonic rocks and siliciclasts). The loading of the sand fraction is the opposite of all other variables, except for $\mathrm{Sr}$, indicating perhaps a lesser influence of the sand fraction on the chemical composition of samples. Ca is related to hornblende and feldspars.

With regard to core AA-02, factor analyses were applied to three data sets. First, the distribution of variables of scanned samples retrieved from $0-551 \mathrm{~cm}$ depth was studied (Fig. 4c). The order of the factors differs from that of the other core sites: the first factor of AA- 02 corresponds to factor 2 of AA- 05 , and vice versa. Factor 1 of AA-02 (52.9\% of variance, corresponding to F2 of AA-05) is defined by the strong negative loadings of $\mathrm{K}, \mathrm{Ti}, \mathrm{Al}, \mathrm{Fe}, \mathrm{Rb}$ and $\mathrm{Mn}$ and the positive loading of TOC, whereas factor $2(21.3 \%$ of variance, corresponding to $\mathrm{F} 1$ of AA-05) shows $\mathrm{Zr}$ and $\mathrm{Sr}$ on one side and TOC and metals on the opposite side. Second, FA of 26 calibration samples (conventional XRF) showed the typical element distribution of the Hasli-Aare Delta floodplain according to content percentages: $\mathrm{Fe}, \mathrm{Al}, \mathrm{Ti}$ and $\mathrm{Mn}$ (phyllosilicates, metamorphic rocks) related to the silt fraction; $\mathrm{Zr}$ (quartz diorite-syenite, granites) related to the sand fraction and, lastly, a group of $\mathrm{Sr}, \mathrm{Na}$ and $\mathrm{Si}$ (plagioclase, quartz diorite) with weak loadings. Finally, these outcomes are supported by additional FA computation of XRF scanning and grain-size fractions of approximately 300 samples collected from 251 to $551 \mathrm{~cm}$ depth (Fig. 4d).

To conclude, the analysis of the geochemical records of the cores AA-05, AA-10 and AA-02 provides evidence that the chemical composition of the floodplain deposits is influenced by (1) grain size, (2) the lithology of the source area, and (3) soil formation (organic material, leaching of carbonates and redox processes). The following areas of provenance were detected by FA: the southern catchment area comprised plutonic bedrock, the central area a predominance of metamorphic rocks, and (though less clearly) the northern area presented carbonate-rich bedrock. 

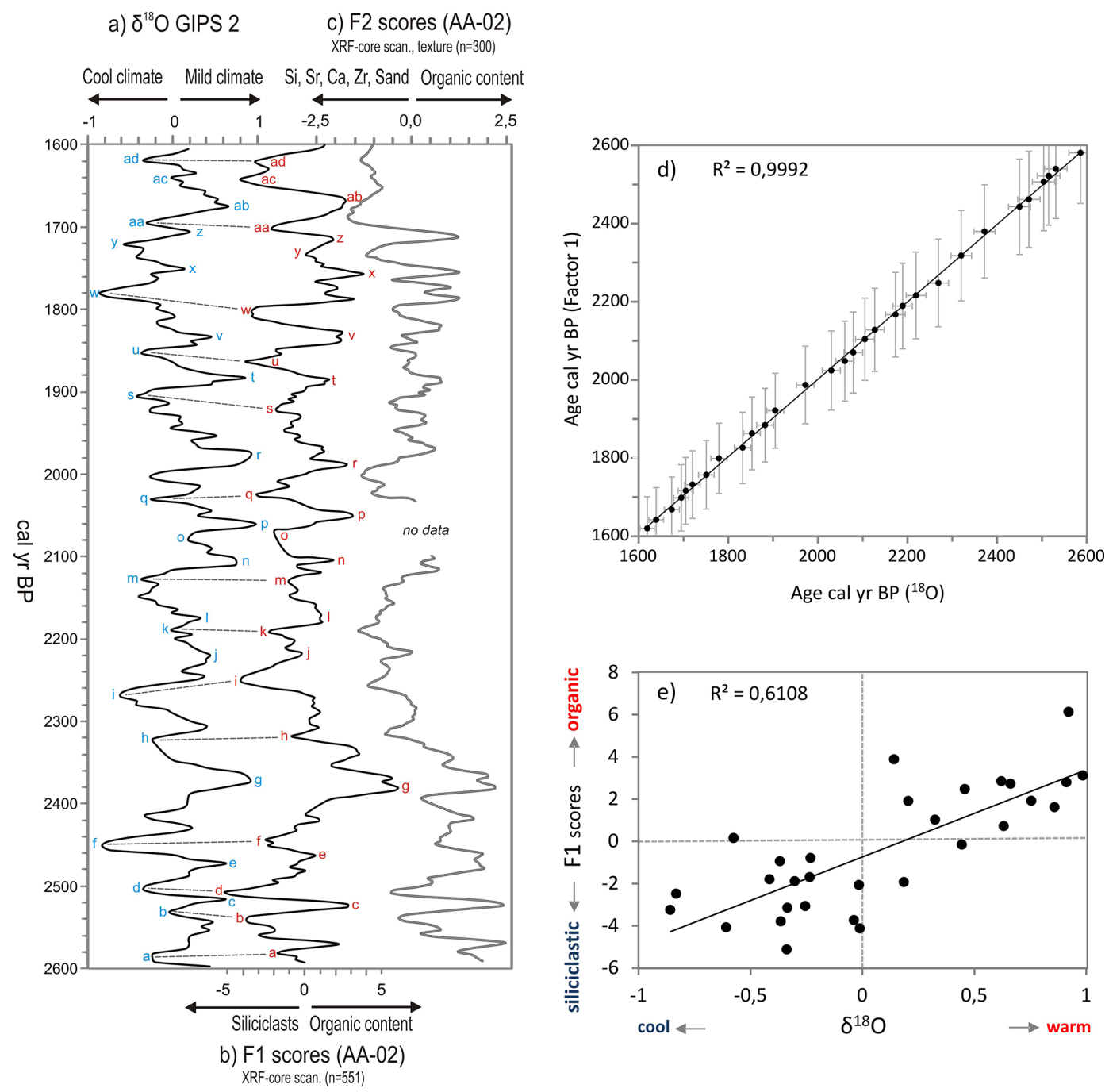

Figure 5. Comparison of the (a) $\delta^{18} \mathrm{O}$ isotope record from the Greenland Ice Sheet Project 2 (GISP2; Stuiver et al., 1997) and (b) factor 1 scores of scanned core AA-02 samples from 2600 to 1600 cal yr BP (3-data-smoothed, approximately 9 years). Correspondence of cool climate pulses and siliciclasts (negative values) are assigned by dashed lines. Maxima and minima of both series $\left(\delta^{18} \mathrm{O}\right.$ and factor 1$)$ were labelled with characters from "a" to "ad". (c) Scores of scanned core AA-02 samples and grain size are plotted for comparison. (d) Comparison of maximum and minimum local events a-ad $(N=30 ;(\mathbf{a}, \mathbf{b}))$ of the $\delta^{18} \mathrm{O}$ isotope record from the Greenland Ice Sheet $(x$ axis; GISP2; Stuiver et al., 1997) and factor 1 scores of scanned core AA-02 samples ( $y$ axis) from 2600 to 1600 cal yr BP. Error bars shown at $\pm 5.0 \%$ for factor 1 scores according to ${ }^{14} \mathrm{C}$ chronology after calibration and at $\pm 1.0 \%$ for ${ }^{18} \mathrm{O}$ (GISP2) according to Stuiver et al. (1997) indicate that the timing of the selected events is consistent. (e) Scatter plot between $\delta^{18} \mathrm{O}$ and $\mathrm{F} 1$ scores of maximum and minimum local events a-ad.

\subsection{Correlation and periodicities}

When the scores of the first factor are plotted against depth, multiple aggradational pulses inside the overbank deposits are detected, which indicate changing sedimentation environments. For example, aggradational pulses in core AA-05 $(0-213 \mathrm{~cm}$ depth) are characterized over the last 700 years by the increase in the phyllosilicate content (metamorphic rocks) and the decline in elements such as $\mathrm{Zr}$ and $\mathrm{Sr}$ associated with granite, quartz diorite and syenite (intrusive rocks at $2528 \mathrm{~m}$ a.s.l. mean altitude) as shown by negative scores of factor 1 (Fig. 3). These negative scores coincide with peaks of $\mathrm{Zr} / \mathrm{Ti}$ ratios and with a total of 26 coarsegrained flood layers, forming seven episodes: 1250-1350, around 1390, 1420-1480, 1550-1620, 1650-1720, 1762 and 1811-1851 cal yr AD. Eight of these flood layers show Ca / Ti and $\mathrm{CaCO}_{3}$ peaks (Fig. 2) pointing to increased discharge contribution from catchment areas with calcareous bedrock (lower Aare catchment, mean altitude: $1578 \mathrm{~m}$ a.s.l.) during floods that occurred around 1390, 1480, 1660, 1700 and 1760 cal yr AD. 

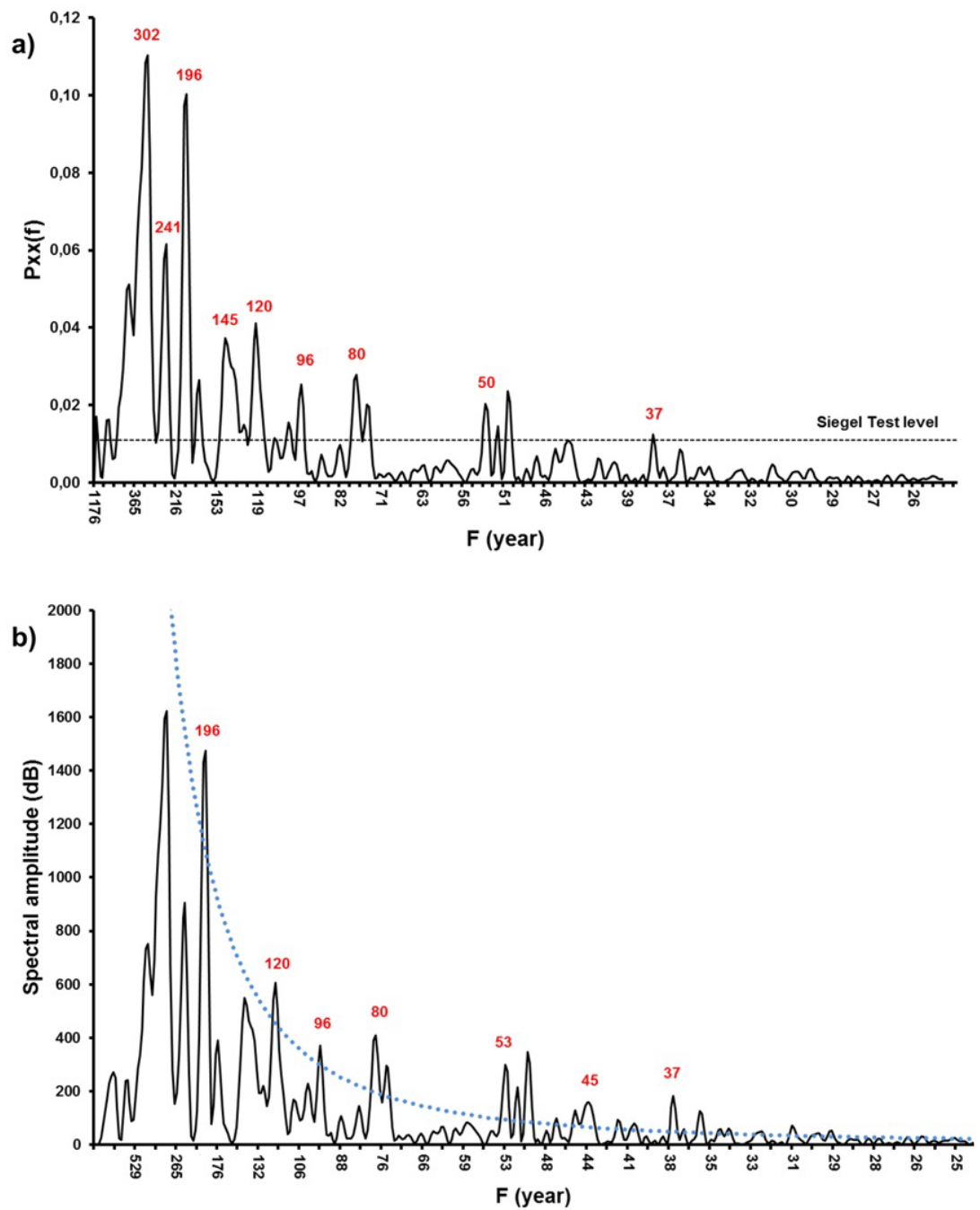

Figure 6. (a) Harmonic analysis of the composite palaeoflood record of the Hasli-Aare Delta plain. Dotted line represents critical level for the Siegel test and significant frequencies are shown in years. (b) Red-noise spectra of the composite palaeoflood record. Dotted line shows false-alarm level. Significant frequencies are shown in years.

Figure 3 illustrates a significant correlation between the clusters of flood layers detected in core AA-05 and the Aare flood episodes recorded by historical sources (Sect. 4.5). However, the magnitude of the $\mathrm{Zr} / \mathrm{Ti}$ peaks does not systematically coincide with the historical flood intensity, for the following reasons: firstly, some flood layers are defined by higher carbonate contribution and decreased $\mathrm{Zr}$ values; secondly, there are changes in the distance from the main channel and in the extension of the flooded area; and, thirdly, historical flood series may also include a range of uncertainties.

The correlation between cores AA-10 and AA- 05 and also with the historical data (Fig. 3) provides arguments for the validity of flood reconstruction in the Hasli-Aare floodplain. However, the amplitude of factor 1 and the total number of 13 flood layers in core AA-10 are lower than in core AA-05, indicating a lower sensitivity of the floodplain records, due to the influence of flooding by Lake Brienz on the one hand (e.g. deposition of suspended load during the AD 1390 and 1762 flood episodes; see Sect. 4.5) and to the change in the distance from the channel as a consequence of displacement of delta lobes on the other. The lowering of the outlet of Lake Brienz by $3.5 \mathrm{ft}$. $(1 \mathrm{~m})$ between AD 1852 and 1862 (Willi, 1932) may have decreased the blocking effect on the river drainage caused by high lake levels. Since the termination of the Hasli-Aare correction project in AD 1875, geochemical and grain size flood proxies of both core sites have been noticeably masked because sedimentation processes have been reduced by structural flood mitigation (Sect. 4.5).

To study the flood dynamics prior to periods of persistent human impact on landscape, as shown by palynological data (falls in arboreal pollen and mesic tree pollen percent- 
ages; Schulte et al., 2009a), we focused our analysis particularly on core AA- 02 , which provides high-resolution records from 2600 to 1600 cal yr BP. Figure 5 illustrates the visual correlation between the sedimentary proxies of core AA-2 and the $\delta^{18} \mathrm{O}$ values of the GISP2 record of the Greenland Ice sheet (Fig. 5a; Reimer et al., 2004) over a time slice of 1000 years. Figure $5 \mathrm{~b}$ represents the variability of scores of factor 1 (XRF-scanned samples) defined by siliciclasts (negative scores) and organic content (positive scores). Figure 5c shows scores of factor 2 (XRF-scanned samples and grainsize fractions), where negative scores correspond to $\mathrm{Si}$, $\mathrm{Sr}$, $\mathrm{Ca}, \mathrm{Zr}$ and the sand fraction, whereas positive scores are associated with TOC and metals (Sect. 4.3, Fig. 4d). The curves show a very similar pattern, suggesting that the higher silicate content and elements associated with plutonic rocks from the highest catchment correlates with a cooler climate in Greenland, whereas soil formation and lesser flooding correlate with milder climate pulses.

Finally, Fig. 5d compares the maximum and minimum peaks between $\delta^{18} \mathrm{O}$ and factor 1 and are labelled with characters from "a" to "ad" (Fig. 5a, b). This technique is widely used in the interpretation of palaeoclimate proxies (e.g. Pèlachs et al., 2011). When we compare the timing of local minima and maxima of the two series, the time lags between the respective peaks are always within the dating error intervals. Thus the timing of events in both records is consistent. The scatter plot (Fig. 5e) of F1 scores versus $\delta^{18} \mathrm{O}$ shows a lineal distribution of maximum and minimum local events a-ad. Two groups can be differentiated: the first group is related to maximum values in both variables and documents warm climate and organic-rich sediments; the second group corresponds to minimum values of the variables and evidence cool climate conditions and siliciclastic-rich sediments.

Although trends in geochemical proxies appear to show a close relationship with the climate proxy, it is difficult to evaluate in all cases whether a flood layer corresponds to precise climate pulses (minima or peaks). The reason for this is the inadequate calibration (e.g. for the period 450 $700 \mathrm{cal}$ yr BP) or total lack of any calibration by historical sources (before $700 \mathrm{cal} \mathrm{yr} \mathrm{BP).} \mathrm{Furthermore,} \mathrm{the} \mathrm{question}$ arises of whether there may be time lags between the two data series; for example, $\delta^{18} \mathrm{O}$ values may record delays from 0 to 40 years relative to the ${ }^{14} \mathrm{C}$ production rate (Stuiver et al., 1997; Versteegh, 2005).

Because of the quasi-cyclic pattern of the geochemical delta plain proxies and the possible correlation with the Greenland Ice record (Fig. 5) and the reconstructed summer temperature and spring precipitation of the Alps (Büntgen et al., 2011), spectral analyses were performed. The harmonic analysis (Fig. 6a) was applied to F1 scores from AA05, F1 scores from AA-10, F1 and F2 scores from AA-02 and, finally, to the composite palaeoflood record (AA-05 and AA-02) to detect periodicities in the time series considering noise. The valid signals detected were above the Siegel test level (Fig. 6a, b). Peaks of return intervals $<60$ years were not considered due to the magnitude of the uncertainty intervals in fluvial deposition environments when calibration was not possible.

According to the results (Table 2), the sedimentary record of core AA-2 shows periodicities of around 60, 80, 100 and 205 years for the period from 2600 to 1600 cal yr BP. With regard to the last 700 years, the spectral analysis of the AA05 record suggests the existence of three cycles: 80, 96 and 196 years. Factor 1 of core AA-10 shows periodicities of 60 , 86,102 and 184 years. All the cycles obtained are very similar to the periodicities obtained from the GISP2 record (69, 81, 105 and 208 years; Stuiver et al., 1997), the total solar irradiance $(75,86,105,129$ and 207 years; Steinhilber et al., 2009) and the North Atlantic Oscillation (NAO; 65, 80 and 100 years; Luterbacher et al., 2002). Dendrochronological series provide cycles of reconstructed spring precipitation at intervals of 73, 130 and 200 years (Büntgen et al., 2011). The appearance of the Gleissberg ( 81-year cycle), the $\sim 105$-year and the Suess cycles $(\sim 211$-year cycle; Versteegh, 2005) in the data series analysed provides evidence that the influence of solar forcing can be considered as a major driver of floods in the Aare catchment.

\subsection{Historical flood series}

The reconstruction of the Hasli-Aare floods yield a total of 35 flood damage events for the period 1480-2012 (Fig. 7), with flood intensities ranging from 0.5 to 4.5 according to the classification of Table 1 and Eq. (1). Thirty-three of the 35 reported events (94\%) occurred during the extended summer period (JJAS). This temporal distribution is consistent with the findings of Weingartner et al. (2003), who analysed instrumental flood data from 85 alpine catchments in Switzerland. Five extraordinary episodes (AD 1342-1343, 1480, 1551, 1762 and 1831 (Fig. 7) were defined as catastrophic floods $(M \geq 3.5)$, and 11 events as severe floods $(2 \leq M<3.5), 3$ of which reached intensity level 3. Finally, 21 small and medium floods $(M<2)$ were recorded after AD 1855. Before AD 1855 no records of $M<2$ were obtained, because minor damage was not recorded in written sources. In contrast to this lack of flood data, a cluster of nine minor floods between AD 1855 and AD 1875 can be interpreted partially as an artefact which reflects a turning point in the human-environment interaction regarding hydrological hazards. Firstly, after the destructive events of AD 1831 and 1851, local residents were more sensitive to hydrological hazards; secondly, they were more likely to report minor or medium flood damage in order to force the cantonal and state authorities to fund the creation of a solid river embankment; and, thirdly, floods easily eroded the infrastructure of the Hasli-Aare correction project during the period of its construction from AD 1867 to 1876 (Willi, 1932) and were therefore reported and measured (AD 1875) by engineers (Hählen, 2007). 
From AD 1480 to 2012, 15 severe and catastrophic floods $(M \geq 2)$ in the Hasli-Aare were caused by three rainfall episodes, three rainfall-snowmelt episodes, three thunderstorm events and one rainfall episode with thunderstorm (five events without information). All catastrophic floods $(M \geq 3.5)$ recorded not only extraordinary flooding in the lower Hasli Valley floor but also damage in one or more headwater subcatchments and/or tributaries. The extensive impact of the AD 1342-1343, 1480, 1762 and 1831 floods in the Hasli-Aare catchment coincides with the greater volume and spatial distribution of flood damage in Swiss catchments (Röthlisberger, 1991). Moreover, these data indicate episodes of long lasting rainfall or rainfall plus snowmelt as a consequence of higher temperatures and snowlines. The cause of the extraordinary AD 1551 event in the Hasli Valley is not known, but the lack of damage in other Swiss catchments may suggest local heavy precipitation. A scenario of a single glacier outburst flood is unlikely because from the historical and instrumental data of the Lütschine catchment we can assume that flood crests did not produce severe damage in the deltas after spreading approximately $20 \mathrm{~km}$.

The magnitude of the damage and extent of flooding in the Hasli Valley is illustrated by the following examples. According to the historical sources, the most catastrophic floods destroyed entire villages - Bürglen, Tschingeln, Hinterluchena and Niederhufen in AD 1551 (Aare) - or parts of villages as in Balm in AD 1551 (Aare) and Meiringen in 1342-1343, 1762 and 1851 (Alpbach). Flooding of larger areas of the lower Hasli Valley floor corresponded to flood intensities $M \geq 3$; the area was described as a "continuous lake" (AD 1851), where "boats crossed the highest fences" (AD 1762) or "only trees and stables were visible" (1867; Willi, 1932; Kurz and Lerch, 1979; Mätzener, 1984). Many of these floods introduced important changes in the floodplain morphology, particularly shifts of the Aare main channels (AD 1499, 1762, 1831), and caused massive aggradation of gravel, stones and boulders. Both floodplain dynamics (Fig. 1) were documented by historical maps published by Mirani in AD 1766, Wyss in 1813 and Dufour in 1876 and by geological cross sections (Llorca and Schulte, 2014). Mass destruction of houses and loss of farmland, as in AD 13421343, 1499, 1551, 1762 and 1831, generated famine, abandonment, migration, requests for assistance and subsequent reorganization.

An important issue in the research undertaken is the question of whether historical floods are reproducible by the proxy data from sediment records. No fewer than 13 of the 15 severe and catastrophic events which occurred before the termination of the Hasli-Aare correction in AD 1875 are also detected by coarse-grained flood layers and $\log (\mathrm{Zr} / \mathrm{Ti})$ peaks in core AA-05 (Fig. 3b) and to a lesser extent also in core AA-10 (Fig. 3c and d), where the influence of Lake Brienz is noticeable. For example, although the AD 1762 flood is the largest event recorded in the Hasli Valley during the last half millennium, no coarse-grained flood layer

$$
\text { 高 }
$$

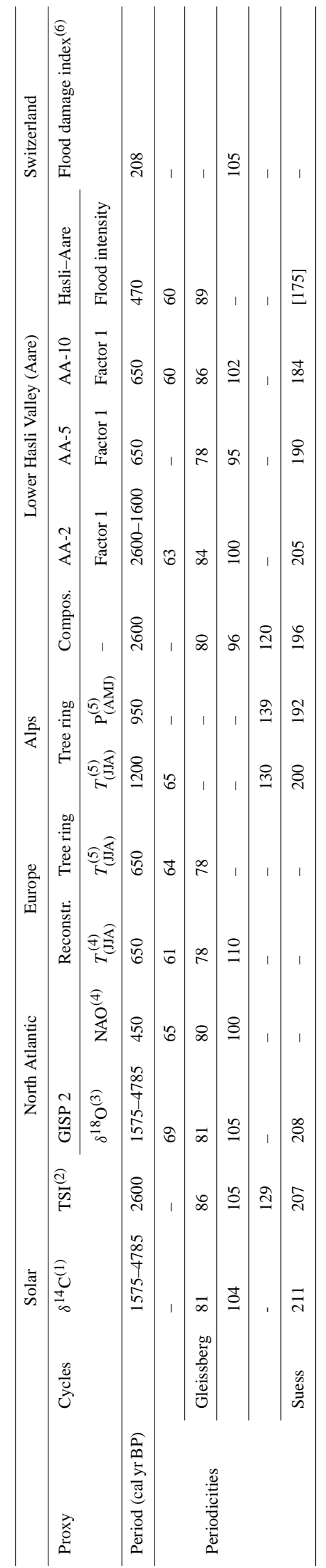


was detected in core AA-10 and only a minor change was observed in the geochemistry (factor 1). This contradiction can be explained by the rise of Lake Brienz (Willi, 1932) and flooding of the distal area of the delta, meaning that only suspended fine material was deposited at the AA-10 site. The area of fine material deposition and delimitation of the flooding can be easily traced from the SPOT satellite (30 August 2005; Swisstopo) images, taken 6 days after the AD 2005 flood, and from oblique aerial photographs taken on the day after the flood.

The flood dynamics in the Hasli Valley changed significantly after AD 1875, as illustrated in Figs. 7 and 8. For climatic and anthropogenic reasons, floods of intensities $M \geq 1$ disappeared completely between AD 1876 and 1976. First, a flood gap in Swiss hydrological time series is reported by Röthlisberger (1991), Schmocker-Fackel and Naef (2010) and Stucki et al. (2012). Pfister (1999) attributed the decrease of floods to long-term summer precipitation minima between AD 1935 and 1975. Peña and Schulte (2014) stress the lack of extreme weather conditions from AD 1944 to 1972 in Switzerland as a consequence of the predominance of negative Summer North Atlantic Oscillation (SNAO). Second, according to Gees (1997), river regulation, embankments and reservoirs substantially reduced smaller and medium floods after AD 1854. In the Hasli Valley several actions contributed to the flood mitigation in the Aare River system (Sect. 4.1): lowering of the lake level in AD 1862, the channelling of the Aare riverbed (AD 1875), the commissioning of interconnected reservoirs and power plants since AD 1932 and, more recently, the construction of retention basins (AD 2013). For example, in AD 1875, the year the Hasli-Aare correction was completed, a flood with a discharge of $351 \mathrm{~m}^{3} \mathrm{~s}^{-1}$ did not produce any damage or flooding in the lower Hasli Valley, whereas 1 year before, in AD 1874, bridges were destroyed and two breaches in the new embankment were eroded, even though the flood level of the Aare River was a foot lower than in AD 1875 (Hählen, 2007).

\subsection{Estimations of historical flood discharges}

Determining the historical flood discharges that defined the damage threshold (Fig. 7) is a challenging task and in this paper we present only some rough estimates. From the historical data and the discharge measurements by engineers during the construction of the embankment in AD 1875 (Hählen, 2007) we can assume that before the termination of the Aare correction in AD 1875 the level of $351 \mathrm{~m}^{3} \mathrm{~s}^{-1}$ (a conservative estimate) produced damage of intensity $M_{\mathrm{AA}} \geq 1$. Since AD 1875, flooding of this magnitude disappeared from the data series until AD 1977 and only in tributaries and headwater subcatchments was any damage noted, and then only on a small scale $\left(M_{\mathrm{AA}}=0\right.$ and $\left.M_{i}>0\right)$. The new threshold of flooding in the lower Hasli is located approximately between 360 and $370 \mathrm{~m}^{3} \mathrm{~s}^{-1}\left(M_{\mathrm{AA}}=1\right)$. For example, during the flood of 10 October $2011\left(367 \mathrm{~m}^{3} \mathrm{~s}^{-1}\right)$ the water slightly overtopped levees at Unterbach and caused small pounded lakes $(M=1)$. However, since AD 1932 several connected reservoirs have been in operation for hydroelectric power generation. The floods that occurred during the spring (e.g. the flood of 12 May 1999) and early summer were retained for the most part in the headwater of the upper Hasli Valley because the reservoirs recorded lower levels due to electricity production during the winter months. Through late summer, retention capacity is lower (the reservoir level is high, due to snowmelt), but it can still contribute to flood reduction as it did in $\operatorname{AD} 2005\left(M_{\mathrm{AA}}=2\right.$ and $M_{i}=1$, then $M=2+0.5-$ see Eq. (1) - when the level was low due to inspection work) and in $\mathrm{AD} 2011\left(M_{\mathrm{AA}}=1\right.$; dry autumn; Richli and Andres, 2012). Flood levels, reconstructed from lichenometric dating at three sample profiles downstream of the Räterichsbodensee Dam during summer AD 2014 (results not included in this paper), indicate that floods still affected the upper HasliAare subcatchment after AD 1932, but that the flood levels of known floods are much lower than in AD 1922, the year of the last major flood before the construction of the reservoirs.

Under the present river configuration, the AD 2005 event with a discharge of $444 \mathrm{~m}^{3} \mathrm{~s}^{-1}$ corresponded to an intensity of 2.5, but if it had occurred before AD 1875 it might have reached intensity 3.5 , in which case it would have qualified as catastrophic. According to the measurements and estimations of the hydroelectric power company Kraftwerke Oberhasli AG, the retention of the reservoirs in the Hasli-Aare catchment ascended to $120 \mathrm{~m}^{3} \mathrm{~s}^{-1}$ during the peak discharge of 21 August 2005 (21:00-22:00). Without the influence of these reservoirs the possible peak discharge at the gauge station Brienzwiler may have reached around $563 \mathrm{~m}^{3} \mathrm{~s}^{-1}$ (Fig. 7). Likewise, various events of intensity 1 and 1.5 may correspond to intensities $M \geq 2$ and as a result may have been considered as severe events. Interestingly, during the 1860 s engineers originally planned a channel capacity of $510 \mathrm{~m}^{3} \mathrm{~s}^{-1}$ (Hählen, 2007) which may have marked the possible magnitude of catastrophic floods. To conclude, the changing configuration of the mitigation structures and retention capacities makes it difficult to homogenize the flood intensities series before and after river correction and reservoir construction, at least in the data series analysed.

\subsection{Evidence of the AD 1342 and/or 1343 flood episodes}

The catastrophic flood episode of AD 1342 and/or 1343, cited in the German literature as the "Magdalena flood", is described as the outstanding flood episode in central Europe during the last millennium. The number of pulses, their exact dates and drivers are controversially discussed in Bork and Bork (1987), Röthlisberger (1991), Glaser (2001), Kiss (2009), Wetter et al. (2011), Zbinden (2011) and Herget et al. (2014). Whereas in central and northern Switzerland historical information about this flood wave has been analysed (Pfister and Hächler, 1991; Siegenthaler and Sturm, 1991; Röthlisberger, 1999; Wetter et al., 2011), little is 


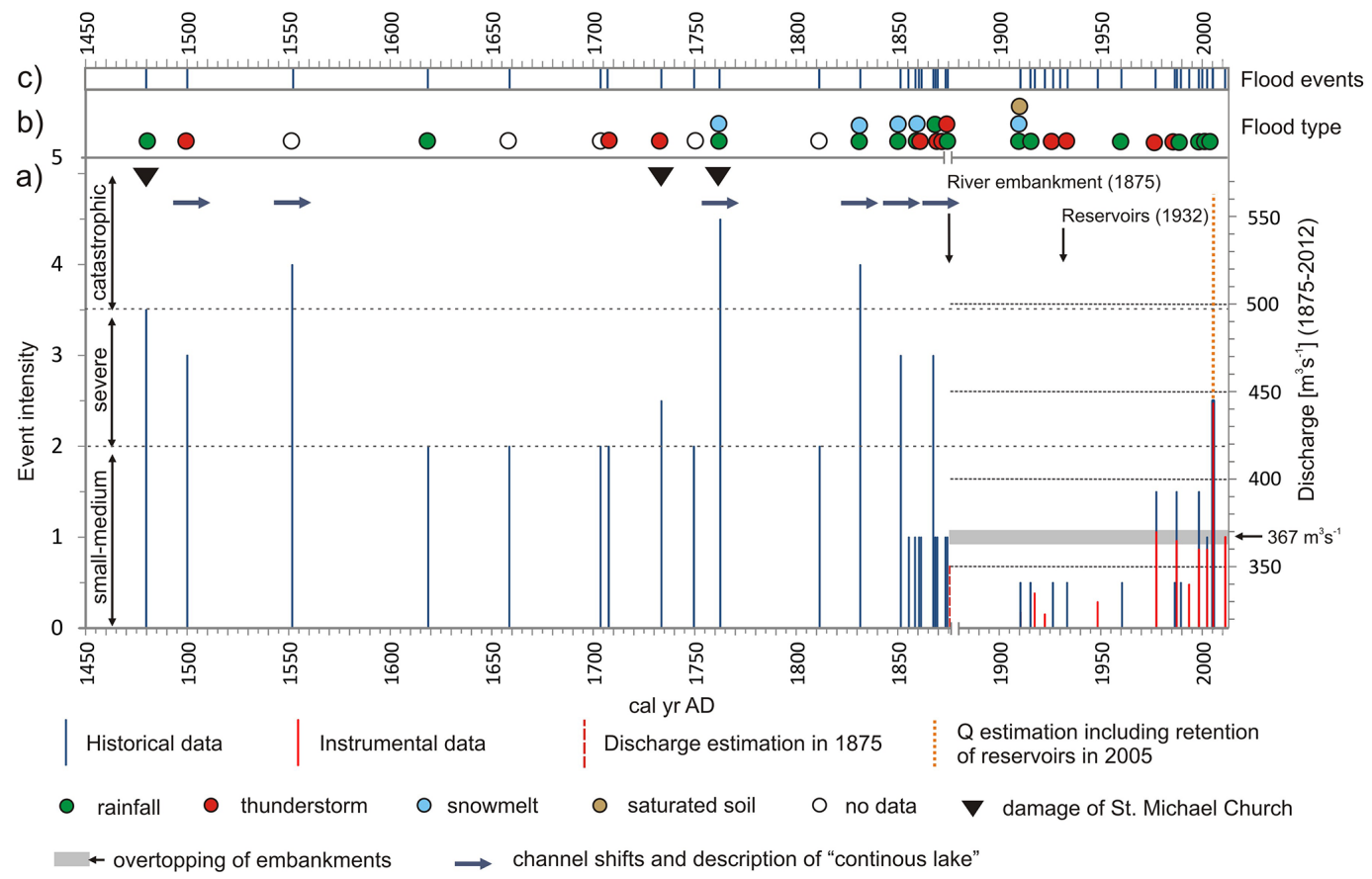

Figure 7. Flood chronology of the Aare River in the Hasli Valley from AD 1480 to 2012. (a) Flood intensities reconstructed from documentary and geomorphological evidence (blue columns) and instrumental data (red columns). Event intensities $\mathrm{M}$ (left scale; referring to Table 1 and Eq. 1) are estimated for the period AD 1480-2012, whereas maximum annual discharges $>300 \mathrm{~m}^{3} \mathrm{~s}^{-1}$ (right scale) recorded at the Brienzwiler gauging station are valid for the period AD 1908-2012. Discharge measurements in AD 1875 were conducted on-site by engineers of the Aare correction project. Measured discharges and event intensity level are influenced by structural mitigations such as river embankments since AD 1875 and retention capacities of reservoirs since AD 1932 as in the case of the 2005 flood (arrows). Triangles represent damage to the Sankt Michael church by flooding and severe aggradation caused by the Alpbach River. (b) Hydro-climatological cause of floods (legend below) according to historical written sources, WSL flood data bank, expert reports, newspapers and precipitation data. (c) Composite flood frequencies. Data as in (a) .

known about its impact in western Switzerland. Turbidite beds recorded in the sediments of Lake Urner and dated between $990-1250$ and $1270-1420$ cal yr BP $(2 \sigma$; Siegenthaler and Sturm, 1991) were probably deposited by the AD 1343 flood in the River Reuss.

There are no written reports of the AD 1342 and/or 1343 event in the Hasli Valley, but interesting evidence can be inferred from sedimentary and geoarchaeological data. Although changing distances between source and deposit (e.g. shifts of river channels) influence the deposition environment and nature of sediments, it is striking that the flood beds identified in core AA-05 at $211-200 \mathrm{~cm}$ depth and in core AA-10 at $197-189 \mathrm{~cm}$ show the highest scores of factor 1 , high sand content $(85 \%)$ and $\log (\mathrm{Zr} / \mathrm{Ti})$ values. Organic beds just below and above the coarse-grained overbank deposits are dated by radiocarbon to 1179-1269 and 1279$1394 \mathrm{cal}$ yr BP $(2 \sigma)$. These ages are quite consistent, but they do not allow distinguishing a priori between different catastrophic flood events, such as the AD 1275, 1342 and/or 1343 episodes (Röthlisberger, 1991).

However, geoarchaeological data recorded from excavations of the Sankt Michael church in the village of Meirin- gen, located on the alluvial fan of the Alpbach, indicate several construction and restoration phases (phases I-XIII) of which some are related to flood events (e.g. AD 1733 and 1762). According to Gutscher (2008) the church was damaged twice by destructive floods just before AD 1351, the date engraved on the church bell, but no particular flood event was named. The first flood damaged the northern wall (phase VI according to Gutscher, 2008) which was subsequently rebuilt (phase VII). During a second flood, massive aggradation filled the church with debris up to a height of $3.5 \mathrm{~m}$. In this case the ancient church was not excavated, due either to the volume of material or to the short recurrence interval of the events. Consequently, the new church floor was built right on the flood sediments (phase VIII). Gutscher (2008) argues that the two floods occurred within a very short time because the archaeological findings showed that the church walls were not plastered with mortar after the first event; this would have been highly unusual for a church in the Bernese Oberland during the 14 th century.

To conclude, the sedimentary data of the floodplain and the geoarchaeological findings of the Sankt Michael church suggest that the AD 1342-1343 flood episodes very likely 


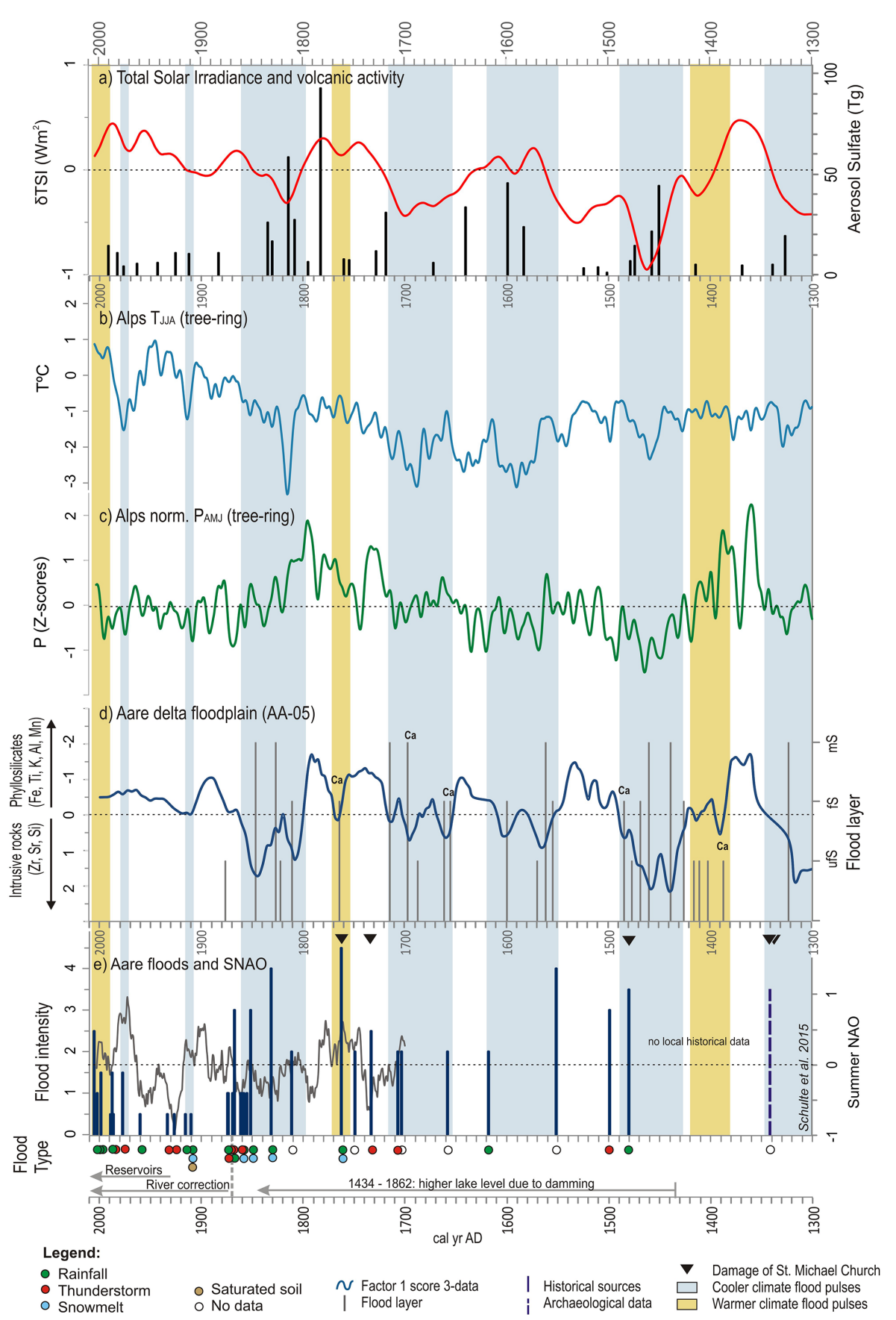

Figure 8. Comparison between historical flood reconstruction of the Hasli-Aare and solar and volcanic activity and climate proxies (13002010 cal yr AD). (a) 40-year averaged variations of total solar irradiance (Steinhilber et al., 2009) and annual stratospheric volcanic sulfate aerosol injection, Northern Hemisphere (Gao et al., 2008). (b) JJA temperature anomalies (13-year Gaussian low-pass filter) in the European Alps reconstructed from larch density series (Büntgen et al., 2006). (c) AMJ precipitation anomalies (13-year Gaussian low-pass filter) in the European Alps reconstructed from larch density series (Büntgen et al., 2006). (d) Sedimentary palaeoflood proxy from the Aare Delta plain in the lower Hasli Valley (this paper). Factor 1 scores (3-data centred moving average equivalent to 13-year resolution) of chemical composition of core AA-05 samples and coarse-grained flood layers (ufS: silty fine sand; fS: fine sand; mS: middle sand). (e) Historical flood chronology of the Aare River (Hasli Valley) from documentary, archaeological and geomorphological evidences like in Fig. 7 (this paper). Triangles represent damage to the Sankt Michael church by flooding and severe aggradation caused by the Alpbach River. 


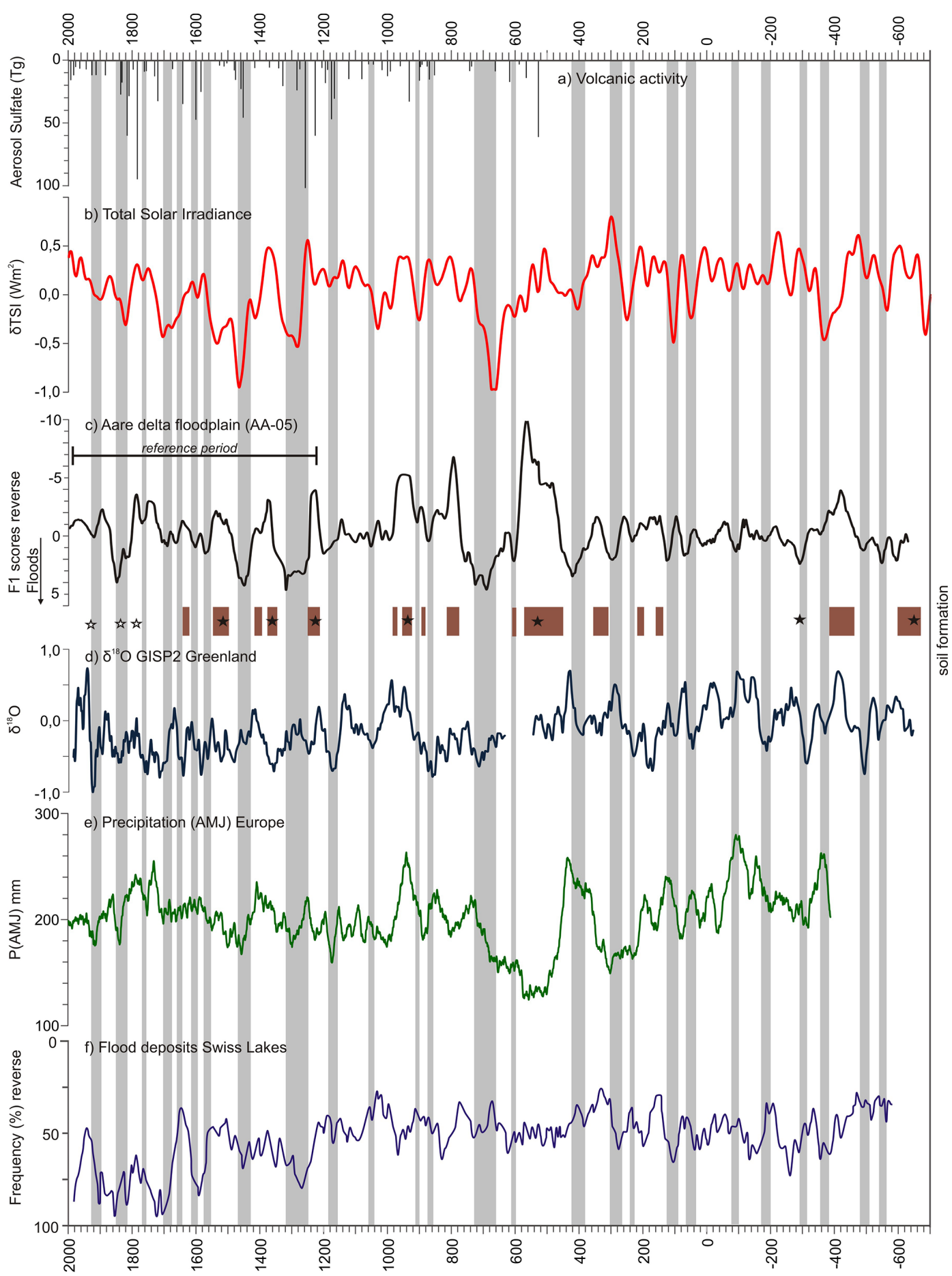

Figure 9. Comparison between reconstructed palaeofloods in the Hasli Valley and solar and volcanic activity and climate proxies from $600 \mathrm{cal} \mathrm{yr} \mathrm{BC}$ to $2000 \mathrm{cal}$ yr AD. (a) Annual stratospheric volcanic sulfate aerosol injection, Northern Hemisphere (Gao et al., 2008). (b) 40year averaged variations of total solar irradiance (Steinhilber et al., 2009). (c) Composite sedimentary palaeoflood proxy at a 21 -year resolution from the Aare Delta plain in the lower Hasli Valley (this paper). Factor 1 scores of chemical composition of delta plain samples. Peat and organic soils are shown by dark shaded rectangles. Stars indicate the stratigraphical position of datings. (d) $\delta^{18} \mathrm{O}$ of the GISP2 ice core from Greenland (Stuiver et al., 1997) at a 21-year resolution. (e) 21-year smoothed AMJ precipitation anomalies in central Europe reconstructed from oak ring width series (Büntgen et al., 2011). (f) Flood chronology derived from flood deposits of 10 lakes from the northern slope and central area of the Swiss Alps (50-year moving average; Glur et al., 2013). 
left their mark on the Hasli Valley, but it is not possible to assign the events to specific flood episodes during AD 1342 and 1343 in central Europe or Switzerland. According to the flood pattern reconstructed by time series from AD 14802012, the 1342-1343 flood episodes occurred very likely during the summer months (e.g. July 1342, July-September 1343; Herget et al., 2015; Kiss et al., 2015), so the episodes of February and November 1342 should be excluded.

\section{Discussion}

The spectral analysis conducted (Sect. 4.4) provides evidence that the frequencies of the variability of sedimentary floodplain proxies are similar to the cycles of palaeoclimatic records of the Alps, Europe and the North Atlantic and, furthermore, are in agreement with the solar cycles. Moreover, the synchronous evolution of the geochemical proxies of core AA-02 and the GISP2 (Fig. 5) points to the fact that floods in the Hasli-Aare are influenced not just by local factors but by regional factors and/or by the Northern Hemisphere climate. To investigate the possible mechanisms and drivers of catchment dynamics, the discussion focuses firstly on the flood records of the last 700 years (Sect. 5.1), in which palaeoclimate information obtains adequate resolution (Sect. 4.3) and is supported by historical data (Sect. 4.5), and secondly on the possibility of extending this palaeoflood model to the past 2600 years (Sect. 5.2).

\subsection{Palaeofloods and climate variability of the last 700 years}

Figure 8 illustrates the quasi-cyclic variability of factor 1 scores, where maxima represent silty beds rich in phyllosilicates and organic matter. This facies is related to in situ soil formation during phases of minor flooding or flood gaps, soil erosion in the catchment, and the deposition of fine-grained crystalline material particularly from areas with metamorphic rocks. According to Figs. 8 and 9, phases of smaller floods correlate with high total solar irradiance (Steinhilber et al., 2009) and with higher summer temperatures (JJA) in the European Alps as reconstructed from recent and historic larch ring density chronologies (Büntgen et al., 2011).

The increased input of phyllosilicates during warmer summers can be attributed to a variety of mechanisms such as permafrost degradation (limit of continuous permafrost is located at approximately 2600-2900 m a.s.1.), rainfall, and repeated snowmelt processes (rainfall on snow cover and frozen soil, snowmelt due to the entry of warm air masses, snowfall on unfrozen soil) during late spring and summer. These connected dynamics particularly affect the area of erodible metamorphic rocks and shallow soils (Lithosols and Regosols) with low water retention capacities at an average altitude of $2171 \mathrm{~m}$ a.s.l. (619-4076 $\mathrm{m}$ a.s.1.) and their impact can be demonstrated most clearly in the Rotlaui and Spre- itlaui tributaries. In the AD 2005 flood, large debris flows on the Rotlaui fan yielded $500000 \mathrm{~m}^{3}$ of materials into the Aare River system, and since then pulses in AD 2009, 2010 and 2011 on the Spreitlaui fan have yielded $600000 \mathrm{~m}^{3}$ more (Hählen, 2010; Huggel et al., 2012). After the sediment input of $100000 \mathrm{~m}^{3}$ by the Spreitlaui creek on 12 August 2010, within a few days the Aare transferred $20000 \mathrm{~m}^{3}$ of sand, gravel and stones over a distance of $7 \mathrm{~km}$ to the basin of Innertkirchen (intermediate storage; Hählen, 2010). The absence of any increased discharge of the Aare during this period indicates the high connectivity between the upper slope, the fluvial system and the delta floodplains. However, negative scores of $\mathrm{F} 1$ or $\mathrm{Zr} / \mathrm{Ti}$ peaks are not recorded during warmer climate pulses. We suggest that the effect of permafrost degradation on erosional processes in the plutonic bedrock area of the Aare catchment is less important because more than half of this domain ( $2528 \mathrm{~m}$ a.s.l.) has been located above the permafrost limit (2600-2900 m a.s.l.) during the present warmer climate (Institut für Kartographie, 2004).

The possible correlations of periods of low flood frequencies with the regional climate variability are shown in Fig. 8. In addition, we used a method to express the similarities between series: the Pearson product moment correlation coefficient (Maddy and Brew, 1995). The results show negative and significant ( $p<0.01 ; N=566)$ correlations between F1 scores (21-year homogenized proxy data) and late spring and early summer precipitation $(r=-0.46)$, summer temperature $(r=-0.32)$ and TSI $(r=-0.53)$.

Periods of reduced flooding and deposition of phyllosilicates (maximum scores) correlate with positive late spring and early summer precipitation anomalies (Büntgen et al., 2011) from 1350 to 1410,1500 to 1560 , around 1660 and from 1720 to $1810 \mathrm{cal}$ yr AD. The combination of wet springs and warm summers produced increased discharges during spring and early summer, whereas during warm high summer, the critical season for large flood events (in the HasliAare $92 \%$ occur during this time), less stored water volume is available. The historical data from the Hasli-Aare indicate that floods triggered by thunderstorms correspond mostly to warmer climate pulses or intermediate climate (Figs. 7, 8). However, Pfister (1999) and Weingartner et al. (2003) stressed that local or short thunderstorms only rarely produce severe flooding in mid- and large-size catchments.

Against this background, it is interesting that during the warmer climate pulses around 1390, 1660 and 1762 cal yr AD, coarse-grained beds with a noticeable carbonate contribution (high $\mathrm{Ca}, \mathrm{CaCO}_{3}$ and $\mathrm{Sr}$ values) are recorded. These elements reflect sediment yield from limestone areas, thus indicating rainfall events that also affected the lower catchment $(1578 \mathrm{~m}$ a.s.l. mean altitude) of the Hasli-Aare. This was the case in the AD 1762 event, the largest flood ever recorded by historical sources in the lower Hasli Valley (Sect. 4.5). The lateral contribution from tributaries with limestone bedrock was demonstrated by the tremendous description of the catastrophic Alpbach flood 
which caused massive aggradation in the village of Meiringen (Mätzener, 1984). According to the historical flood analysis of all Swiss catchments conducted by Röthlisberger (1991) and validated later by Schmocker-Fackel and Naef (2010), the AD 1762 event was the outstanding flood episode in Switzerland during recent centuries and had an intensive effect on the Rhine, Reuss and Linth basins. The flood was caused by the combination of 4 days of rainfall, high temperatures and snowmelt (Mätzener, 1984; Röthlisberger, 1991).

Nevertheless, the aggradation of the palaeoflood clusters (1250-1350, 1420-1490, 1550-1620, 1650-1720 and 18111867 cal yr AD) occurred predominantly during periods with cooler summer temperatures (Büntgen et al., 2006, 2011; Trachsel et al., 2012), reduced solar irradiance, clusters of increased Northern Hemisphere aerosol sulfate from major volcanic eruptions (Gao et al., 2008) and phases of drier spring climate (Fig. 8). However, there are also flood periods such as the pulse around 1580 that do not follow the pattern of the TSI: the maximum of TSI of around 1600 coincides with the lowest summer temperature $\left(T_{\mathrm{JJA}}\right)$ reconstructed by dendrochronology. The disagreement between TSI and $T_{\mathrm{JJA}}$ needs further research. Our flood data are in agreement with the lower $T_{\mathrm{JJA}}$ in the Alps that could be influenced by two episodes of volcanic eruption.

Furthermore, the 1550-1620 and 18111851 cal yr AD clusters coincide with the flood-rich periods in Switzerland identified by Schmocker-Fackel and Naef (2010), Glur et al. (2013) and Peña et al. (2014). Minimum scores of factor 1 and the highest $\mathrm{Zr} / \mathrm{Ti}, \mathrm{Si} / \mathrm{Ti}$ and $\mathrm{Ca} / \mathrm{Ti}$ ratios were obtained in beds dominated by coarse-grained flood layers (Figs. 2, 3). The correlation matrix shows negative coefficients of $r=-0.58$ between $\mathrm{Si}$ and TOC and $r=-0.47$ between $\mathrm{Zr}$ and TOC $(n=198)$. According to these relations, floods with high flow velocities deposited medium- and coarse-grained overbank beds of resistant siliciclasts (e.g. quartz) and heavy minerals (e.g. zircon) eroded from the highest catchment with plutonic bedrock ( $2528 \mathrm{~m}$ a.s.l. mean altitude; Figs. 1 and 8 ).

Cooler climate trends promote glacier advance and more extensive snow cover. This greater water storage in turn produces higher base discharges and surface runoff during summer months (Stucki et al., 2012). As regards the spatial significance of lower climatic snowlines and glacier advances, it is important to note that the area susceptible to melting processes associated with rainfall episodes and abrupt temperature increases (e.g. caused by Foehns) can grow substantially in mountain topographies and may shift to the high summer (flood) season. Moreover, the permanence of snow cover and snow patches through the summer favours the existence of impermeable areas and saturated soils in adjacent terrain, thus increasing surface runoff on slopes. For example, the magnitude of the most recent major Aare floods (AD 1831 and 1851) is believed to be related to the increased melting processes of advanced glacier and extended snow cover (cool-moist winters; Pfister, 1999) as a consequence of the marked trend towards higher summer temperatures and a higher altitude of the $0^{\circ} \mathrm{C}$ line. This interpretation is supported by the major sediment yield from the upper catchment with plutonic bedrock.

The influence of land use on flood discharges and sediment yield is difficult to assess because different kinds of anthropogenic activity may have had a compensatory effect. For example, the maximum deforestation and damage caused by debris flows during the second half of the 19th century (Willi, 1932; Marlot, 1915) are not recorded in the sedimentary records of the Hasli-Aare floodplain due to the effects of the structural mitigation of river management (in the form of embankments and river correction).

From the historical data (this paper), the study of flood damage in Switzerland over the last 200 years (Peña and Schulte, 2014) and temperature reconstruction (Luterbacher et al., 2002; Büntgen et al., 2006; Trachsel et al., 2012) we infer that the cooler climate trends during the Little Ice Age reflected important rainfall episodes with snowmelt triggered by North Atlantic dynamics. With regard to the frequency of severe and catastrophic floods in Switzerland since AD 1800, Peña and Schulte (2014) analysed the influence of the principal atmospheric circulation patterns based on the standardized daily anomalies of sea level during the summer months of July and August. The Summer North Atlantic Oscillation is inferred from the monthly sea level pressure fields over the North Atlantic and Europe, generated by Luterbacher et al. (2002) for the years 1659-2000. This grid was developed, under the assumption of stationarity in the statistical relationships, using a transfer function based on the combination of early instrumental station series and documentary proxy data from Eurasian sites. The function is derived over the 1901-1990 period and was used to reconstruct the 500-year large-scale SLP (sea level pressure) fields (Luterbacher et al., 2002). Episodes of major floods in the central Swiss Alps are triggered by negative SNAO (Hurrell et al., 2003) phases during the last pulses of the Little Ice Age (AD 1817-1851 and 1881-1927 flood clusters) and by positive SNAO phases during the warmer climate from AD 1977 to present. Floods during positive SNAO are related to cyclones of Mediterranean origin that cross central Europe as they move to the northeast along the $\mathrm{Vb}$ track. Floods during negative SNAO are associated with cold fronts originating over the Atlantic, tracing a northwest to southeast passage (Peña et al., 2014).

A comparison between the historical flood intensities (Fig. 7) and F1 score (Fig. 8) from the lower Hasli Valley and the SNAO index (annual values and 13-year smoothed data; Peña et al., 2014) from AD 1700 to 2000 shows the following relation: floods $M \geq 1$ in the Aare occurred mostly during positive trends of SNAO phases. This pattern is clearly displayed by the AD 1749 flood and by the modern floods since AD 1977 (1977, 1987 and 2005). In the case of the severe AD 1703, 1707, 1811, 1831 and 1851 floods, the episodes correlate to short positive SNAO pulses following years or even decades dominated by negative SNAO. This combina- 
tion points to the importance of the effect of snowmelt (e.g. together with extraordinary heavy rainfall; Weingartner et al., 2003) during short warm episodes within cool climate periods characterized by larger snow cover and glaciers. Only the AD 1733 and 1867 floods occurred during negative SNAO pulses dominated by cool-moist air masses transferred by North Atlantic front systems. The AD 1762 flood, the largest event recorded in the Hasli Valley, shows a singular pattern defined by a negative annual SNAO index within a longer pulse of positive SNAO mean values, probably because of the relevance of drivers other than snowmelt. This is supported by the historical sources that report an exceptional 4day rainfall episode (Mätzener, 1984; Röthlisberger, 1991).

Palaeofloods in the upper Engadine (eastern Switzerland) from 1177 to 2000 cal yr AD were reconstructed by Stewart et al. (2011) from lake sediments. According to their results, floods may be related to strong negative anomalies of SLP over western Europe and the western Mediterranean that caused increased advection of anomalous humid south westerlies between 1950 and 2000 cal yr AD.

In addition, atmospheric dynamics during the winter season may also have a delayed influence on summer flood frequencies, especially in terms of snow accumulation and glacier dynamics (Stewart et al., 2011). Wirth et al. (2013) underline the coincidence between increased floods in the southern Alps, reconstructed by flood layers in lake deposits, and overall annual and decadal negative NAO phases during the Little Ice Age, due to a southerly position of the Atlantic storm tracks.

In the upper Aare catchment located on the northern slope of the Alps it is difficult to establish a correlation, because major floods are recorded during years of both positive and negative NAO phases. However, during the Little Ice Age NAO values smoothed by an 11-year running mean correlate positively with the geochemical flood proxy factor 1 scores from 1667 to $1820 \mathrm{cal}$ yr AD. The contribution of siliciclasts from the highest catchments (positive F1 scores) deposited during floods correlate with a negative NAO mode (cooler winters). Afterwards, this correlation disappears. Whereas NAO shows a positive trend, negative F1 scores (flooding) continue until AD 1867, due to the effect of considerably warmer summer temperatures on melting processes.

As regards the low-frequency flood pattern at centennial scale (Fig. 8), geochemical proxies of the Hasli-Aare floodplain record four major quasi-cycles from AD 1350 to 1876. Cycles start during warmer summer climate conditions with the deposition of phyllosilicates (positive scores), followed by flood layers with carbonate contribution (around 1380, 1480, 1658, 1700 and 1762 cal yr AD). The cycle continues with a progressive increase in material from the high-altitude plutonic bedrock (negative scores) and ends with a flood peak defined by maximum negative scores. These terminations at around 1460, 1590, 1720 and 1850 cal yr AD coincide with minima of summer temperatures in the Alps (Büntgen et al., 2006), TSI (Steinhilber et al., 2009) and negative SNAO trends (Hurrell et al., 2003; Peña et al., 2014).

\subsection{The possibility of creating a 2600-year palaeoflood calendar}

When calibration by historical sources has been possible, the information about palaeofloods and mechanisms contained in the floodplain sediment record of the lower Hasli Valley has been shown to be accurate (Sect. 5.1). Because periodicities of 80, 96, 120 and 196 years of the composite record (Table 2$)$ are very similar to the solar cycles $(86,105,129$ and 207 years), we plotted factor 1 scores alongside TSI (Steinhilber et al., 2009) over the last 2600 years (Fig. 9). Furthermore, periods depicted by formation of peat and organic soils (lithostratigraphic data) were shown by dark shaded rectangles. Figure 9 illustrates that periods of organic soil formation and deposition of phyllosilicates (peaks of factor 1) match the maxima of TSI, pointing to reduced flood activity during warmer climate pulses (as already shown by the separate analysis of each core). To validate the regional signal of these proxies, ages of peat horizons were compared to the data obtained from the Lütschine (cores IN-02, IN04, IN-08, IN-30) and Lombach floodplains (LB-10), where previous studies (Schulte et al., 2008, 2009a, b) also indicated a coincidence between soil formation and solar activity. Common periods of peat formation between the three different floodplains are recorded from 500 to $450 \mathrm{cal} \mathrm{yr} \mathrm{BC}$, around $100 \mathrm{cal} y \mathrm{AD}$, from 125 to $250 \mathrm{cal}$ yr AD, from 450 to 550 cal yr AD and around $800 \mathrm{cal}$ yr AD. In recent centuries the palaeoenvironmental records in the Lütschine and Lombach have been disturbed by the impact of human activity, such as river correction and the draining of wetlands.

Deposition of siliciclasts with major contributions from plutonic bedrock (minimal factor 1 scores, shaded areas in Fig. 9) occurred during solar minima or occasionally with time lags of around 30 years. Apart from a few cases, these aggradation pulses also correlate closely with the cooler climate in Greenland (North Atlantic) recorded by negative anomalies of $\delta^{18} \mathrm{O}$. Therefore, the geochemical pattern, traced with precision over the last 700 years (Fig. 8), can be assumed to be valid for the last two and a half millenniums of floodplain dynamics. This outcome is especially relevant for the understanding of alpine rivers, because before 1100 cal yr AD the human impact on landscape in the Bernese Alps was relatively low and sporadic phases of clearance were followed by forest recovery (Schulte et al., 2009a). In consequence, rivers and flood dynamics are assumed to be natural.

The interpretation of the comparison between sedimentary floodplain proxies and summer temperature and late springearly summer precipitation in Europe and the Alps reconstructed from tree rings (Büntgen et al., 2006, 2011) is more difficult over the last 2600 years than over the 700 -year reference period (Sect. 5.1). For example, some periods of peat 
formation (from 450 to 580, around 800 and $950 \mathrm{cal}$ yr AD) which correlate with increased solar irradiance and $\delta^{18} \mathrm{O}$ do not coincide with increased summer temperature in Europe and the Alps (Büntgen et al., 2006, 2011). This observation may suggest that peat formation is conditioned by the timing of flood gaps rather than by warmer summer temperatures. Furthermore, during the last 2600 years not all floods occurred during cooler summer climate pulses, as previously shown by the data of the reference period (Figs. 8, 9); flood processes are controlled by drivers and mechanisms of various kinds, related to summer climate (atmospheric circulation, type of precipitation, variations of snowline, abrupt temperature rises and permafrost degradation) on the one hand, and to winter climate variability (water storage by snowcover and glaciers) on the other, as discussed in Sect. 5.1.

Figure 9 also illustrates the possible correlation of our data with the 2600-year long flood reconstruction based on flood deposits from 10 lakes in Switzerland (Glur et al., 2013). A good coincidence of flood pulses was detected from $1100 \mathrm{cal}$ yr AD to present, whereas from 2600$1100 \mathrm{cal}$ yr AD some events do not coincide. However, this observation should not be interpreted as a complete mismatch of the two curves. For example, it is absolutely clear that the outstanding flood gap in the Aare River from 450 to $580 \mathrm{cal}$ yr $\mathrm{AD}$, which coincides with an unusually longlasting dry late spring-early summer period as shown by the dendrochronological data (Büntgen et al., 2011), is reflected in the composite sedimentary lake record of the Swiss Alps as a relatively calm phase with very low variability.

Focusing on the correlation with precipitation proxies, it is striking that from 400 to $700 \mathrm{cal}$ yr AD floods occurred during both wetter and drier climate pulses, whereas after the outstanding wet climate anomaly from 350 to 450 cal yr AD, during the "Migration Period", the flood regime switched to a pattern characterized by predominantly dry spring-early summer conditions. This has been consistently recorded over the last 700 years.

At our present stage of knowledge, the attribution of individual floods to specific climate pulses may be uncertain without cross-correlation with historical data series or characteristic climate anomalies (marker events). To conclude, alluvial floodplain deposition during floods corresponds quite closely to solar and $\delta^{18} \mathrm{O}$ variations and broadly follows the pattern and frequencies of floods in the last 700 years (the period for which historical sources are available).

\section{Conclusions}

Our results suggest that composite palaeoflood series can be generated from high-resolution delta plain sediments of the Hasli-Aare, which reproduce the fluvial dynamic and related mechanisms, including trends, clusters and gaps of floods in alpine catchments. We calibrated natural proxies compiled from sedimentary, geochemical and geomorphological data by textual and factual sources and by instrumental data. Before the termination of the River Aare correction in AD 1875, no fewer than 12 of the 14 historically recorded extreme events since AD 1480 were also identified by coarse-grained flood layers, $\log (\mathrm{Zr} / \mathrm{Ti})$ peaks and factor 1 anomalies. The determination of historical flood discharges that defined the damage threshold is complex, and only rough estimations are presented. From the historical and instrumental data we assume that before AD 1875 the magnitude of $351 \mathrm{~m}^{3} \mathrm{~s}^{-1}$ (a conservative estimate) produced damage of small-medium intensity $M \geq 1$, whereas discharges of $500 \mathrm{~m}^{3} \mathrm{~s}^{-1}$ or higher probably caused catastrophic damage $(M \geq 3.5)$.

Spectral analysis of the geochemical and pollen time series and climate proxies $\left(\delta^{14} \mathrm{C}\right.$, TSI, $\delta^{18} \mathrm{O}$ isotopes from the Greenland Ice Sheet, temperatures and precipitation reconstruction from tree rings, NAO, and SNAO) evidence similar periodicities around 80, 100, 120 and 200 years. Thus, the mechanisms of the flood processes are strongly influenced by the North Atlantic dynamics and solar forcing. The composite 2600-year sedimentary floodplain record illustrates that periods of minor floods and flood gaps inferred from organic soil formation and deposition of phyllosilicates (mediumhigh catchment area) match the maxima of total solar irradiance.

The palaeoflood clusters defined by flood layers (e.g. $1300-1350,1420-1490,1550-1620,1650-1720$ and $1811-$ 1851 cal yr AD) with contribution of siliciclasts from the highest plutonic bedrock areas occurred predominantly during periods of reduced solar irradiance, cooler summer temperatures and phases of drier spring climate. Cooler climate trends promote glacier advance, more extensive snow cover, and snow patches through the summer. Water storage and larger areas susceptible to melting processes associated with rainfall episodes and abrupt rises in temperature can increase surface runoff on slopes and consequently the discharges of alpine rivers.

Evidence of the influence of atmospheric circulation dynamics on alpine flood frequencies is obtained when flood intensities and geochemical proxies from the Hasli Valley and indices of atmospheric modes from AD 1670 and 2000 are compared. Floods with $M \geq 1$ occurred mostly during positive trends of SNAO phases or short positive SNAO pulses (cyclones of Mediterranean origin) following years or even decades dominated by negative SNAO (North Atlantic front systems). This combination underlines the importance of the effect of snowmelt during short warm episodes within cool climate periods characterized by larger snow cover and glaciers. This outcome is also supported by the fact that the 11 -year smoothed negative NAO values (i.e. cool winters) correlate positively with the geochemical flood proxy factor 1 (floods and major contributions from highest catchment areas) from $\mathrm{AD} 1667$ to 1820 .

The results with regard to the compilation of a composite 2600-year palaeoflood record show that alluvial floodplain deposition during floods responds sensitively to climate vari- 
ations broadly following the flood pattern and frequencies of the last 700 years, albeit with a larger margin of uncertainty. Therefore, palaeoflood proxies do not permit the specification of climate or environmental conditions that cause extreme events beyond the information provided by palaeoclimate proxies but contribute complementary palaeoenvironmental data.

\section{The Supplement related to this article is available online at doi:10.5194/hess-19-3047-2015-supplement.}

Acknowledgements. We are grateful to Niels Hählen, Civil Engineering Department Canton Bern, for providing flood data and helpful expert advice. We thank Ulla Röhl and Thomas Westerhold (MARUM - Centre for Marine Environmental Sciences, University of Bremen) for introducing in the XRF core scanning techniques and discussing the XRF data series. We thank also Juan Ignacio Santisteban, Alexandre Badoux and Gerardo Benito for discussing the flood data and geochemical time series and Alberto Martínez Monreal for mineralogical analysis. Furthermore, we thank Johanna Lomax, Marta Baró Albos, Maura Coca Sabater and João Pedro Penilo for carrying out geochemical analyses and helping in the field retrieval of sediment cores. Daniel Bürki from the Kraftwerke Oberhasli AG provided the data of retention of the reservoirs during the 2005 flood event. We appreciate the collaboration of local administration and property owners concerning drilling permits. Special thanks goes to Hansueli and Sigrid Balmer-Rose (Wilderswil) for providing local historical information, logistic support, plum tart and for their hospitality during more than 10 fieldwork campaigns. The Swiss Federal Institute for Forest, Snow and Landscape Research WSL provided the flood damage data for the period 1972-2010. Instrumental precipitation records were downloaded from the IDAWEB database (MeteoSwiss). Information on discharges of the upper Aare River of the Brienzwiler gauging station were obtained from the BUWAL. The work of the FluvAlps Research Group (PaleoRisk; 2014 SGR 507) was funded by the Catalan Institution for Research and Advanced Studies (ICREA Academia 2011) and the Spanish Ministry of Education and Science (CGL2009-0111; CGL2013-43716-R).

Edited by: G. Blöschl

\section{References}

Arnaud, F., Revel, M., Chapron, E., Desmet, M., and Tribovillard, N.: 7200 years of Rhône river flooding activity in Lake Le Bourget, France: a high-resolution sediment record of NW Alps hydrology, The Holocene, 15, 420-428, 2005.

Bork, H.-R. and Bork, H.: Extreme jungholozäne hygrische Klimaschwankungen in Mitteleuropa und ihre Folgen, Eiszeitalter und Gegenwart, 37, Hannover, 109-118, 1987.

Büntgen, U., Frank, D. C., Nievergelt, D., and Esper, J.: Summer Temperature Variations in the European Alps, A.D. 755-2004, J. Climate, 19, 5606-5623, 2006.
Büntgen, U., Tegel, W., Nicolussi, K., McCormick, M., Frank, D., Trouet, V., Kaplan, J. O., Herzig, F., Heussner, K.-U., Wanner, H., Luterbacher, J., and Esper, J.: 2500 years of European climate variability and human susceptibility, Science, 331, 578582, 2011.

Carvalho, F.: Análisis multi-proxy paleoambiental y modelización de registros sedimentarios fluviales en los Alpes Suizos, Ph.D. thesis, University of Barcelona, Spain, 259 pp., 2014.

Carvalho, F. and Schulte, L.: Morphological control on sedimentation rates and patterns of delta floodplains in the Swiss Alps, Geomorphology, 198, 163-176, 2013.

Ebersbach, R., Hoyer, W., and Zahnd, E.: Ein "Repräsentatives Inventar" für den Kanton Bern?, Archäologie Bern 2010, Bern, Switzerland, 249-271, 2010.

Gao, C., Robock, A., and Ammann, C.: Volcanic forcing of climate over the past 1500 years: An improved ice core-based index for climate models, J. Geophys. Res., 113, D23111, doi:10.1029/2008JD010239, 2008.

Gees, A.: Analyse historischer und seltener Hochwasser in der Schweiz: Bedeutung für das Bemessungshochwasser, Geographica Bernensia G53, Bern, Switzerland, 1997.

Glaser, R.: Klimageschichte Mitteleuropas. 1000 Jahre Wetter, Klima, Katastrophen, Wissenschaftliche Buchgesellschaft Darmstadt, Darmstadt, 227 pp., 2001.

Glur, L., Wirth, S. B., Büntgen, U., Gilli, A., Haug, G. H., Schär, C., Beer, J., and Anselmetti, F. S.: Frequent floods in the European Alps coincide with cooler periods of the past 2500 years, Scientific Reports, 3, 2770, doi:10.1038/srep02770, 2013.

Gutscher, D.: Die Michaelskirche von Meiringen als archäologischer Zeuge früherer Naturkatastrophen, Archäologie Bern, Jahrbuch des Archäologischen Dienstes des Kanton Bern, Bern, Switzerland, 133-148, 2008.

Guyard, H., Chapron, E., St-Onge, G., Anselmetti, F. S., Arnaud, F., Magand, O., Francus, P., and Mélières, M.-A.: High-altitude varve records of abrupt environmental changes and mining activity over the last 4000 years in the Western French Alps (Lake Bramant, Grandes Rousses Massif), Quat. Sci. Rev., 26, 2644 2660, 2007.

Hählen, N.: Geschichte der Korrektion der Aare zwischen Meiringen und Brienz und Entsumpfung des Haslitals, Oberingenieurskreis I, Tiefbauamt des Kantons Bern, Thun, 15 pp., 2007.

Hählen, N.: Murgänge Spreitgraben Guttannen: Fachleute Naturgefahren Schweiz, available at: FAN; www.planat.ch/de/partner/ fan/ (last access: 23 February 2012), Nationale Plattform Naturgefahren PLANAT, Bern, Switzerland, 11 pp., 2010.

Hansen, J., Ruedy, R., Sato, M., and Lo, K.: Global surface temperature change, Revs. Geophys., 48, 1-19, 2010.

Hantke, R.: Eiszeitalter, Die jüngste Erdgeschichte der Schweiz und ihrer Nachbargebiete. Bd. 1, Ott, Thun, Switzerland, 1980.

Hartmann, D. L., Klein Tank, A. M. G., Rusticucci, M., Alexander, L. V., Brönnimann, S., Charabi, Y., Dentener, F. J., Dlugokencky, E. J., Easterling, D. R., Kaplan, A., Soden, B. J., Thorne, P. W., Wild, M., and Zhai, P. M.: Observations: Atmosphere and surface, in: Climate change 2013: The physical science basis, edited by: Stocker, T. F., Qin, D., Plattner, G. K., Tignor, M., Allen, S. K., Boschung, J., Nauels, A., Xia, Y., Bex, V., and Midgley, P. M., Intergovernmental Panel on Climate Change, Working Group I Contribution to the IPCC Fifth Assessment Report (AR5), Cambridge Univ Press, New York, 159-254, 2013. 
Heiri, O., Lotter, A. F., and Lemcke, G.: Loss on ignition as a method for estimating organic and carbonate content in sediments: reproducibility and comparability of results, J. Paleolimnol., 25, 101-110, 2001.

Herget, J., Kapala, A., Krell, M., Rustemeier, E., Simmer, C., and Wyss, A.: The millennium flood of July 1342 revisited, Catena, Elsevier Publication, ISSN0341-8162, doi:10.1016/j.catena.2014.12.010, 2014.

Huggel, C., Clague, J., and Korup, O.: Is climate change responsible for changing landslide activity in high mountains?, Earth Surf. Process. Landf., 37, 77-91, 2012.

Hurrell, J. W., Kushnir, Y., Visbeck, M., and Ottersen, G.: An overview of the North Atlantic Oscillation, in: The North Atlantic Oscillation, Climatic Significance and Environmental Impact, edited by: Hurrell, J. W., Kushnir, Y., Ottersen, G., and Visbeck, M., AGU Geophysical Monograph, Copyright by the American Geophysical Union, 134, 1-35, doi:10.1029/GM134, 2003.

Inventar Historischer Verkehrswege der Schweiz: Strecke BE 44 Brienz-Meiringen, Bundesamt für Strassen ASTRA, Bern, Switzerland available at: http://www.bve.be.ch/bve/de/index/ mobilitaet/mobilitaet_verkehr/langsamverkehr/historische_ verkehrswege.html (last access: 23 February 2014), 1992.

Irmler, R., Daut, G., and Mäusbacher, R.: A debris flow calendar derived from sediments of lake Lago di Braies (N. Italy), Geomorphology, 77, 69-78, 2006.

Jones, A. F., Macklin, M. G., and Brewer, P. A.: A geochemical record of flooding on the upper River Severn, UK, during the last 3750 years, Geomorphology, 179, 89-105, 2012.

Kiss, A.: Floods and weather in 1342 and 1343 in the Carpathian basin, J. Environ. Geogr., 2, 37-47, 2009.

Koinig, K. A., Shotyk, W., Lotter A. F., Ohlendorf, C., and Sturm, M.: 9000 years of geochemical evolution of lithogenic major and trace elements in the sediment of an alpine lake - the role of climate, vegetation, and land-use history, J. Paleolimnol., 30, 307320, 2003.

Kurz, C. and Lerch, C.: Geschichte der Landschaft Hasli, 694 pp., Meiringen, Brügger AG, 1979.

Kylander, M. E., Ampel, L., Wohlfarth, B., and Veres, D.: Highresolution $\mathrm{X}$-ray fluorescence core scanning analysis of Les Echets (France) sedimentary sequence: New insights from chemical proxies, J. Quat. Sci., 26, 109-117, 2011.

Laigre, L., Arnaud-Fassetta, G., and Reynard, E.: A 7300 year record of palaeohydrology in the Swiss Rhône River floodplain (Valais, Switzerland): Geomorphology and sustainability, 8th International conference (AIG) on Geomorphology, Paris, France, 27-31 August, p. 371, 2013.

Llorca, J., Schulte, L., and Carvalho, F.: Dinámica sedimentaria histórica en el valle Hasli (Alpes Suizos), in: Avances de la Geomorfología en España 2012-2014, edited by: Schnabel, S. and Gómez Gutiérrez, A., XIII Reunión Nacional de Geomorfología, Cáceres, Spain, 9-12 September 2014, 36-39, 2014.

Luterbacher, J., Xoplaki, E., Dietrich, D., Jones, P. D., Davies, T. D., Portis, D., Gonzalez-Rouco, J. F., von Storch, H., Gyalistras, D., Casty, C., and Wanner, H.: Extending North Atlantic Oscillation Reconstructions Back to 1500, Atmos. Sci. Lett., 2, 114-124, 2002.
Maddy, D. and Brew, I. S.: Statistical Modelling of Quaternary Science Data. Technical Guide 5, Quaternary Research Association, Cambridge, 271 pp., 1995.

Magny, M., Arnaud, F., Holzhauser, H., Chapron, E., Debret, M., Desmet, M., Leroux, A., Millet, L., Revel, M., and Vannière, B.: Solar and proxy-sensitivity imprints on palaeohydrological records for the last millennium in west-central Europe, Quat. Res., 73, 173-179, 2010.

Magny, M., Peyron, O., Gauthier, E., Vannière, B., Millet, L., and Vermot-Desroches, B.: Quantitative estimates of temperature and precipitation changes over the last millennium from pollen and lake-level data at Lake Joux, Swiss Jura Mountains, Quat. Res., 75, 45-54, 2011.

Marlot, A. v.: Die Wildbachverbauung in der Schweiz, Zeits. f. Bauwesen, 65, 280-304, 1915.

Mätzener, H.: Haslital, Haslitaler, Haslitalerberge: Porträt einer Landschaft und ihrer Menschen, Brügger (4.edit), Meiringen, Switzerland, 20 pp., 1984.

Mirani, A.: Karte topographique der Aare uber Haslital zum Brienzersee, Bern, Switzerland, 1766.

Pèlachs, A., Julià, R., Pérez-Obiol, R., Soriano, J. M., Bal, M. C., Cunill, R. and Catalan, J.: Potential influence of bond events on mid-holocene climate and vegetation in southern Pyrenees as assessed from Burg lake LOI and pollen records, Holocene, 21, 95-104, 2011.

Peña, J. C. and Schulte, L.: Effects of solar activities and climate variability on large floods in Switzerland, Bol. Asoc. Geóg. Esp., 65, 469-475, 2014.

Peña, J. C., Schulte, L., Badoux, A., Barriendos, M., and BarreraEscoda, A.: Influence of solar forcing, climate variability and atmospheric circulation patterns on summer floods in Switzerland, Hydrol. Earth Syst. Sci. Discuss., 11, 13843-13890, doi:10.5194/hessd-11-13843-2014, 2014.

Percival, D. B. and Walden, A. T.: Spectral analysis for physical applications: multitaper and conventional univariate techniques, Cambridge University Press, Cambridge, 583 pp., 1993.

Pfister, C.: Wetternachhersage. 500 Jahre Klimavariationen und Naturkatastrophen, Haupt, Bern, 304 pp., 1999.

Pfister, C. and Hächler, S.: Überschwemmungskatastrophen im Schweizer Alpenraum seit dem Spätmittelalter, Würzburger Geographische Arbeiten, 80, 127-148, 1991.

Reimer P. J., Baillie, M. G. L., Bard, E., Bayliss, A., Beck, J. W., Bertrand, C., Blackwell, P. G., Buck, C. E., Burr, G., Cutler, K. B., Damon, P. E., Edwards, R. L., Fairbanks, R. G., Friedrich, M., Guilderson, T. P., Hughen, K. A., Kromer, B., McCormac, F. G., Manning, S., Bronk Ramsey, C., Reimer, R. W., Remmele, S., Southon, J. R., Stuiver, M., Talamo, S., Taylor, F. W., van der Plicht, J., and Weyhenmeyer, C. E.: IntCal04 Terrestrial Radiocarbon Age Calibration, 0-26 Cal Kyr BP., Radiocarbon, 46, 1029-1058, 2004.

Richli, B. and Andres, M.: HWS Aare Bödeli, Untersuchungen zur Zweckmässigkeit von Schutzmassnahmen, Oberingenieurskreis I, Tiefbauamt des Kanton Bern, Thun, 139 pp., 2012.

Röhl, U. and Abrams, L.: High resolution, downhole, and nondestructive core measurements from Sites 999 and 1001 in the Caribbean Sea: Application to the late Paleocene thermal maximum, Proc. Ocean Drill. Program, Sci. Results, 165, 191-204, 2000 . 
Röthlisberger, G.: Chronik der Unwetterschäden in der Schweiz, WSL Bericht 330, Eidgenössische Forschungsanstalt für Wald, Schnee und Landschaft, Birmensdorf, 1991.

Santisteban, J. I., Mediavilla, R., López-Pamo, E., Dabrio, C. J., Ruiz, M. B., Gil, M. J., Castaño, S., and Martínez-Alfaro, P. E.: Loss on ignition: a qualitative or quantitative method for organic matter and carbonate mineral content in sediments?, J. Paleolimnol., 32, 287-299, 2004.

Schaer, A.: Untersuchungen zum prähistorischen Bergbau im Oberhalbstein (Kanton Graubünden), Jahrbuch der Schweizerischen Gesellschaft für Ur- und Frühgeschichte, SGUF-Publikationen, Basel, 86, 7-54, 2003.

Schmocker-Fackel, P. and Naef, F.: Changes in flood frequencies in Switzerland since 1500, Hydrol. Earth Syst. Sci., 14, 1581-1594, doi:10.5194/hess-14-1581-2010, 2010.

Schulte, L., Julià, R., Oliva, M., Burjachs, F., Veit, H., and Carvalho, F.: Sensitivity of Alpine fluvial environments in the Swiss Alps to climate forcing during the Late Holocene, Sediment Dynamics in Changing Environments, IAHS Publ. 325, 367-374, 2008.

Schulte, L., Veit, H., Burjachs, F., and Julià, R.: Lütschine fan delta response to climate variability and land use in the Bernese Alps during the last 2400 years, Geomorphology, 108, 107-121, 2009a.

Schulte, L., Julià, R., Veit, H., and Carvalho, F.: Do high resolution fan delta records provide a useful tool for hazard assessment in mountain regions?, Int, J. Clim. Change Strat. Manage., 2, 197210, 2009b.

Schulte, L., Peña, J. C., Julià, R., Carvalho, F., Llorca, J., Losada, J., Burjachs, F., Schmidt, T., Rubio, P., and Veit, H.: Climate forcing of paleofloods in the Swiss Alps, in: Avances de la Geomorfología en España 2012-2014, edited by: Schnabel, S. and Gómez Gutiérrez, A., XIII Reunión Nacional de Geomorfología, Cáceres, Spain, 9-12 September, 2014, 36-39, 2014.

Schulz, M. and Mudelsee, M.: REDFIT: estimating red noise spectra directly from unevenly spaced paleoclimatic time series, Comp. Geosci., 28, 421-426, 2002.

Schulz, M. and Statteger, K.: SPECTRUM: spectral analysis of unevenly spaced paleoclimatic time series, Comp. Geosci., 23, 929-945, 1997.

Siegel, A. F.: The noncentral chi-squared distribution with zero degrees of freedom and testing for uniformity, Biometrika, 66, 381386, 1979.

Siegenthaler, C. and Sturm, M.: Die Häufigkeit von Ablagerungen extremer Reuss-Hochwasser, Die Sedimentationsgeschichte im Urnersee seit dem Mittelalter, Mitteilungen des Bundesamtes für Wasserwirtschaft, 4, 127-139, 1991.

Steinhilber, F., Beer, J., and Fröhlich, C.: Total solar irradiance during the Holocene, Geophys. Res. Lett., 36, L19704, doi:10.1029/2009GL040142, 2009.

Stewart, M. M., Grosjean, M., Kuglitsch, F. G., Nussbaumer, S. U., and von Gunten, L.: Reconstructions of late Holocene paleofloods and glacier length changes in the Upper Engadine, Switzerland (ca. 1450 BC-AD 420), Palaeogeogr. Palaeoclimatol. Palaeoecol. 311, 215-223, 2011.

Stucki, P., Rickli, R., Brönnimann, S., Martius, O., Wanner, H., Grebner, D., and Luterbacher, J.: Weather patterns and hydroclimatological precursors of extreme floods in Switzerland since 1868, Meteorol. Zeitschr., 21, 531-550, 2012.
Stuiver, M., Braziunas, T. F., Grootes, P. M., and Zielinski, G. A.: Is there evidence for solar forcing of climate in the GISP2 oxygen isotope record?, Quat. Res., 48, 259-266, 1997.

Stuiver, M., Reimer, P. J., and Reimer, R. W.: CALIB Rev 7.0.2 [WWW program and documentation], available at: http://calib. qub.ac.uk/calib/calib.html, last access: 15 April 2014.

Sturm, K., Glaser, R., Jacobeit, J., Deutsch, M., Brázdil, R., Pfister, C., Luterbacher, J., and Wanner, H.: Hochwasser in Mitteleuropa seit 1500 und ihre Beziehung zur atmosphärischen Zirkulation, Petermanns Geographische Mitteilungen, 145, 14-23, 2001.

Tebbens, L. A., Veldkamp, A., van Dijke, J. J., and Schoorl, J. M.: Modelling longitudinal-profile development in response to Late Quaternary tectonics, climate and sea-level changes; the River Meuse, Global Planet. Change, 27, 165-186, 2000.

Trachsel, M., Kamenik, C., Grosjean, M., McCarroll, D., Moberg, A., Brázdil, R., Büntgen, U., Dobrovolný, P., Esper, J., Frank, D. C., Friedrich, M., Glaser, R., Larocque-Tobler, I., Nicolussi, K., and Riemann, D.: Multi-archive summer temperature reconstruction for the European Alps, AD 1053-1996, Quat. Sci. Rev., 46, 66-79, 2012.

Versteegh, G. J.: Solar forcing of climate. 2: Evidence from the past, Space Sci. Rev., 120, 243-286, 2005.

Vischer, D.: Die Geschichte des Hochwasserschutzes in der Schweiz. Von den Anfängen bis ins 19. Jahrhundert, Berichte des BWG, Serie Wasser, Bern, 208 pp., 2003.

Weingartner, R., Barben, M., and Spreafico, M.: Floods in mountain areas - an overview based on examples from Switzerland, J. Hydrol., 282, 10-24, 2003.

Weiss, D., Shotyk, W., Appleby, P. G., Cheburkin, A. K., and Kramers, J. D.: Atmospheric $\mathrm{Pb}$ deposition since the Industrial Revolution recorded by five Swiss peat profiles: Enrichment factors, fluxes, isotopic composition, and sources, Environ. Sci. Technol., 33, 1340-1352, 1999.

Wetter, O., Pfister, C., Weingartner, R., Luterbacher, J., Reist, T., and Trösch, J.: The largest floods in the High Rhine basin since 1268 assessed from documentary and instrumental evidence, Hydrol. Sci. J., 56, 733-758, 2011.

Wilhelm, B., Arnaud, F., Sabatier, P., Crouzet, C., Brisset, E., Chaumillon, E., Disnar, J.-R., Guiter, F., Malet, E., Reyss, J.-L., Tachikawa, K., Bard, E., and Delannoy, J.-J.: 1400-years of extreme precipitation patterns over the Mediterranean French Alps and possible forcing mechanisms, Quat. Res., 78, 1-12, 2012.

Willi, A.: Die Korrektion der Aare und Entsumpfung des Haslitales, Referat gehalten in der Versammlung der Oekonomischen Gesellschaft in Meiringen den 23. Mai 1880, Buchdruckerei H. Ebinger, Meiringen, 64 pp., 1932.

Wirth, S. B., Girardclos, S., Rellstab, C., and Anselmetti, F. S.: The sedimentary response to a pioneer geo-engineering project: Tracking the Kander River deviation in the sediments of Lake Thun (Switzerland), Sedimentology, 58, 1737-1761, 2011.

Wirth, S. B., Glur, L., Gilli, A., and Anselmetti, F. S.: Holocene flood frequency across the Central Alps - solar forcing and evidence for variations in North Atlantic atmospheric circulation, Quat. Sci. Rev., 80, 112-128, 2013.

Zbinden, E.: Das Magdalenen-Hochwasser von 1342 - der "hydrologische Gau" in Mitteleuropa, Wasser Energie Luft, 103, 193203, 2011. 